\title{
Source Profiling of Air Pollution and its Association with Acute Respiratory Infections in the Himalayan Bound Region of India
}

\author{
Manzoor A. Wani \\ University of Kashmir \\ Amit Kumar Mishra ( $\nabla$ amit.mishra.jnu@gmail.com ) \\ Jawaharlal Nehru University, New Delhi

\section{Saloni Sharma} \\ Jawaharlal Nehru University School of Environmental Sciences \\ Ishtiaq A. Mayer \\ University of Kashmir \\ Mukhtar Ahmad \\ India Meteorological Department
}

\section{Research}

Keywords: Himalaya, air pollution, particulate matter, meteorology, planetary boundary layer height, acute respiratory infections

Posted Date: November 9th, 2020

DOI: https://doi.org/10.21203/rs.3.rs-101473/v1

License: (9) (1) This work is licensed under a Creative Commons Attribution 4.0 International License. Read Full License

Version of Record: A version of this preprint was published at Environmental Science and Pollution Research on July 17th, 2021. See the published version at https://doi.org/10.1007/s11356-021-15413-0. 


\section{Abstract}

The studies related to air pollution and its association with human health over the mountainous region are of utmost importance, and are sparse especially over the Himalayan region of India. This study gives an understanding of increase in the occurrence of respiratory diseases due to the accumulation of pollutants during winter season in the Himalayan region (Kashmir valley). The linkages between various atmospheric variables and clinically validated data have been done using various datasets procured from the satellite, model reanalysis and surface observations. Monthly managed data from 20132017 for upper and lower respiratory tract infections is obtained from the Ministry of health, Government of India. Aerosol optical depth, air temperature, and wind speed are significantly related $(p<0.001)$ to the incidence of acute respiratory infections with its peak during winter. Model derived particulate matters having aerodynamic diameters less than $2.5 \mu \mathrm{m}$ $\left(\mathrm{PM}_{2.5}\right)$ shows high contribution of black carbon, organic carbon and sulphate during winter. This is mainly due to the burning of biomass and biofuels (both indoor and outdoor) with low planetary boundary layer height, accumulating high air pollution and deteriorating air quality during winter months that affects the respiratory health of the habitants. The wind roses generated shows the passage of winds from western side of the region surrounded by Pir panjal Himalayan sub division. Concentrated weighted trajectory analysis has shown that most of the winds coming from the western side are taking southward direction before reaching the study area and may be bringing pollutants from Indo-Gangetic Plain. Our study shows that the accumulation of pollutants in the Himalayan valley is owing to the meteorological stability with significant emissions from burning of biomass and biofuels during winter season, that significantly correlated with the incidence of acute respiratory infections in the region.

\section{Introduction}

Air pollution is strongly associated with morbidity and mortality cases across the word, and accurate assessment of its spatial and temporal variation is important for epidemiological studies to estimate the health effects [1]. Air pollution is a major problem faced by the modern civilization having harmful toxicological bearings on the environment and human health [2]. Airborne suspended particulate matter is a serious worldwide concern as it is linked with adverse human health conditions. There have been several epidemiological studies which revealed the association of airborne particulate matter with the incidence of acute and chronic respiratory diseases [3]. Studies related to the exposure of airborne particulate matter have been documented in epidemiological studies related to human health impacts such as cardiovascular and respiratory diseases over last three decades and are broadly distinguished into acute or chronic on the temporal framework $[4,5]$. Ambient air pollution contributes about $8 \%$ to the Global Burden of Diseases (GBD) and is increasing continuously with time due to increase in fine particulate matter (particulate matter having aerodynamic diameter less than or equal to $2.5 \mu \mathrm{m}$ i.e., $\left.\mathrm{PM}_{2.5}\right)$ [6]. Air pollutant such as nitrogen dioxide $\left(\mathrm{NO}_{2}\right)$ is traffic generated air pollutant and harmful to human health [7]. There is a paucity in research related to the health effects of $\mathrm{NO}_{2}$ exposures in smaller urban areas and there is reason to believe that effect of $\mathrm{NO}_{2}$ vary from urban to non-urban areas [1]. Respiratory diseases are commonly encountered in medicine and pose a very high burden on healthcare infrastructure [8]. Chronic obstructive pulmonary disease (COPD) is a one of the major causes of morbidity and mortality worldwide [9]. The existing physical and socio-economic environment has a significant impact on the respiratory illness [10]. According to the reports of GBD, there are almost 2 million premature deaths in India due to ambient air quality and household air pollution. 13 out of 20 cities (across the world) having highest annual level of PM2.5 are in India, which lead to $21 \%$ increase in mortality due to PM2.5 [11]. Besides the variation in the air composition, the meteorological factors also play a very significant role in spreading of contagious air-borne diseases and air pollutants. Temperature, humidity, atmospheric pressure and wind speed are some of the important meteorological variables that determine the transport, dispersion, stability and growth of air pollutant and air borne pathogen in the ambient atmosphere $[12,13]$. Low temperature and atmospheric stability provides ideal condition for growth of various airborne pathogens and accumulation of various air pollutants. Viruses such as human Metapneumovirus (hMPV) and respiratory syncytial virus (RSV) have been found to cause epidemics in winter season in cold and temperate regions [14]. Mortality is considerably higher during the cold winter months (December-March) as compared to other seasons in northern 
hemisphere. In the United Kingdom, around 25,000 deaths occur annually during winter months [15]. Cold winter months are not only associated with an increased number of deaths but also they have a substantial impact on morbidity [15]. There is a constant increase in hospitalization and mortality during winter months, the bulk of which is related to cardiovascular and respiratory diseases [16]. Exposure to severe cold environment has witnessed an increased rate of incidence of respiratory infections [17]. The effects of climatic change, air pollution and its impact on human health and environment are often getting discussed during last two decades [18].

The Himalayan region stretches over 2400 kilometers from west- northwest (Nanga Parbit 8125 meters) to east (Namche Barwa 7755 meters) and is considered to be the roof of the world [19]. Due to human population burst in the last few decades both the Himalayan ecosystem and human society is facing odd environmental changes [20]. Climate change, pollution and continuous land use transformation in the Himalayan region have impacts on human health, where ecological changes and economic inequalities further influence the spread of various kinds of diseases [21]. Unique geographical personality (physical, socio-economic and cultural environment) of the Himalayan region are linked to different morbidity pattern associated with several respiratory tract infections [22]. These geographical aspects of human health could be due to high variability in climatic conditions and atmospheric stability within Himalayan region [22]. Air quality deteriorates significantly during winter months in the Valley region of Kashmir (Himalayas) with highest $\mathrm{PM}_{2.5}$ concentrations ( $350 \mu \mathrm{g} / \mathrm{m}^{3}$ ), which is about six times of the Indian permissible limit [23]. Emissions in the valley region of Kashmir are highest during winter months due to low temperature and dry conditions along with elevated rise of biofuel emissions (burning of leaves and twigs). These biofuels are mostly byproduct of agriculture and horticulture residuals and are found to be the potent causes of rise in pollution level. Back trajectories show the role westerly winds in the contribution of high $\mathrm{PM}_{2.5}$ levels in the Kashmir Himalayas originated mainly from Afghanistan and other surrounding areas [23]. Studies conducted at the Kullu-Manali region of lower Himalaya have shown that the vehicular pollution is producing ultrafine particles which are getting readily absorbed by lungs and causing serious respiratory and neurological disorders [24]. The mechanisms underlying the seasonal variations are not completely elucidated, but can be surely attributed to the changes in the outside and inside air temperature, wind chill factors, exposure to sunlight, air pollution, pattern or food intake and psychological conditions [16]. The relationship between air changes per hour and infection transmission in a closed environment is enigmatic and have a direct impact on incidences of infectious diseases [25]. A study conducted in seven cities situated in the crop burning area of north India has shown the dependence of various pollutants concentration on the meteorology [26]. The concentration of pollutants such as carbon monoxide and volatile organic compounds have been found to be directly linked to atmospheric conditions, causing major respiratory damages to the population [26]. Damage to respiratory and cardiac health due to criteria air pollutants have been found in the Delhi and also revealed the possible health damage to other places due to transport of these pollutants to other regions [27].

Himalayan region is a very cold and temperate region which gets even colder in winter season with humid and stable atmospheric conditions [28]. With the transport and buildup of harmful air pollutants, such stable atmospheric conditions contribute to damaging of respiratory system making it more susceptible and less defensive against further infections such as acute respiratory infections (ARIs) [29]. ARIs include serious respiratory health problems faced mainly by children and elderly population and are caused mostly by viruses [14].

In most of the studies done worldwide ARIs are found to be linked with the meteorological factors such as temperature, humidity and wind speed [30,31]. In India, there has been wide research gaps correlating the incident of respiratory diseases with the environmental factors and we haven't found any study relating respiratory diseases with the meteorological variables and air pollution in Himalayan region. Therefore, with very rapidly changing climatic conditions and transport of pollutants in Himalayan region, the effect of air pollution and meteorological conditions needed to be studied with respect to respiratory health.

\section{Materials And Methods}




\subsection{Study region}

The Himalaya lies in the north of South Asia separating the great plains of India from the mighty Tibetan plateau interspersed by many longitudinal valleys. With north-ward slope movement, the Himalayan range acts as a great climatic barrier between India and Central Asia. Figure 1 shows the map and topographic structure of the study area. The present study pertains to the north-western part of Kashmir valley (largest valley in the entire Himalayan range), lies between pir panjal range and Zanskar range of the Himalayas. An average altitude ranges between 1038 meters to 5185 meters above sea level, with majority of the population inhabited in the belt, i.e., 1038-1600 metres above sea level [22] with an estimated approximately $6967 \mathrm{~km} 2$ comprises of three districts (Kupwara, Baramulla and Bandipora) (Fig. 1). Area with total population of 22.2 lacs constitutes $32.2 \%$ of the total population of the Kashmir valley. About $36 \%$ of the total horticulture land (hectares) of the whole valley is contributed by this region (JK Statistical Digest 2016). The study area has more rural characteristics, poor infrastructure along with perpetual backwardness. The physiographic attributes have contributed the study area popularly known as, "gate of winds" thereby owing it great importance [22].

\subsection{Meteorological data}

Meteorological data (air temperature, atmospheric pressure, wind speed and direction, and rainfall) were provided by the Indian Meteorological Department (IMD Srinagar) month wise for the period of 2013-2017. Planetary boundary layer height (PBLH) which determines the environmental capacity for the dispersion of atmospheric pollutants, measured by parcel method and by temperature and humidity gradients, i.e., temperature, wind, turbulence quantities and concentration of pollutants [32]. Wind chill factor (WCF), an index to appraise the apparent temperature felt on the exposed skin by the combination of air temperature, wind speed, and relative humidity, were calculated by the formula given by National Weather Service, USA [33].

$\mathrm{WCF}=35.74+0.6215 \mathrm{~T}-35.75\left(\mathrm{~V}^{0.16}\right)+0.4275 \mathrm{~T}\left(\mathrm{~V}^{0.16}\right)$

where $\mathrm{T}=$ Air temperature ${ }^{0} \mathrm{C}, \mathrm{V}=$ Wind Speed $(\mathrm{mph})$. Seasonal wind rose which shows the direction and speed of winds blow in the region over a period of time was generated from Microsoft Excel 2010.

\subsection{Atmospheric composition data}

Data of monthly air pollution contribution to total $\mathrm{PM}_{2.5}$ (black carbon, organic carbon, sulphate, dust and sea salt) for the period of 2013-2017, were retrieved from Modern-era retrospective analysis for research and applications, version 2 (MERRA-2) which is a global reanalysis product that assimilate satellite observations of atmospheric constituents and their interactions with other physical variables (https://gmao.gsfc.nasa.gov/reanalysis/MERRA-2/data_access/) [34]. Aerosol optical depth (AOD) from moderate resolution spectroradiometer (MODIS; collection 6; https://ladsweb.modaps.eosdis.nasa.gov/) at $550 \mathrm{~nm}$ wavelength (combined data product of terra and aqua satellites) is used to understand the monthly and yearly aerosol loading in the atmosphere. All AOD products are monthly averaged over the given coordinates from 2013-2017. The details about MERRA-2 and MODIS products and its validity/comparison over Indian region can be found elsewhere [34-37].

\subsection{Backward wind trajectory analysis}

Backward wind trajectory air mass analysis helps us in finding geographically potential source region which could be adding the particulate matter at the receptor site. Concentrated weighted trajectory analysis is done using backward wind trajectory data obtained from HYSPLIT model [38] from year 2013-2017 for the months January, April, July and October to see the density of wind trajectory at any area in the given time period. We have run the HYSPLIT model to get the backward trajectory air masses started within a period of 72 hours, monthly analyzed at 12 am and at a height of $500 \mathrm{~m}$. Five years 
(2013-2017) data of latitude and longitude of these trajectories were merged together for each month in a single file and these data were plotted as a function of density on the map [39].

\subsection{Demographic data}

Total population, fuel used for cooking, horticulture land in hectares, annual vehicular registrations were obtained from JK statistical digest 2016, JK transport 2018 and Census of India 2011.

\subsection{Health data}

Monthly data related to acute respiratory infections (ARIs) were obtained from integrated disease surveillance program (IDSP) under ministry of health, government of India, for the period of 2013-2017. Incidence rate defined as the number of new cases in the total population in a specified time [40]. It was used to measure the frequency of morbidity pattern of acute respiratory infections (ARIs) that can be useful in predicting the risk factor of the population to develop a given disease and can be calculated by formula:

Incidence rate $(\mathrm{IR})=\frac{\text { Number of new cases of diseases in a specified time period }}{\text { Total population at risk at a given period of time }} \times 1000$

\subsection{Statistical Analysis}

Pearson's coefficient of correlation is used to see the linear relationship between various meteorological variables (air temperature, atmospheric pressure, relative humidity, rainfall, wind speed, wind chill factor and aerosol optical depth) with the incidence rate of ARIs. Step wise multiple regression which signifies the most contributing factors (Independent variables) affecting dependent variables, by eliminating least significant independent variables were carried to identify the potent meteorological factors affecting ARIs in the study region. Analysis of variance (ANOVA) F-test, a statistical model to estimate the variation among and between the groups was performed to test the difference between two or more means with statistical significance. Multi collinearity test were also carried to check the degree of relationship among independent variables.

\section{Results And Discussion}

\subsection{Association of aerosol load and meteorological variables with incidence rate of ARIs}

This study region surrounded by Himalayas has been witnessing erratic climatic and unprecedented weather conditions with changing seasons that is directly attributing to the health of people as seen in the study. We have compared the monthly time series data of incidence rate of acute respiratory infections (IR_ARIs) with seven different meteorological and aerosol parameters (air temperature, wind speed, relative humidity, wind chill, rainfall and AOD). Meteorological conditions with high air temperature and high humidity tends to cease the growth of influenza viruses and other infectious agents and therefore these meteorological variables can be a very useful tool for spread and surveillance of such viruses. [41]. The monthly variations in meteorological parameters and IR_ARIs from 2013-2017 is shown in Table 1. Average air temperature from 2013-2017 were recorded $\left( \pm 4.18^{\circ} \mathrm{C}\right)$ in winter months, with low wind speed $2.2 \mathrm{mph}$, low relative humidity $59.4 \mathrm{~g} / \mathrm{m}^{3}$, and low wind chill (below $2^{0} \mathrm{C}$ ). With the beginning of spring season, the region experiences a sharp increase of air temperature $\left(13^{\circ} \mathrm{C}\right)$ (from the average recorded temperature in winter months from 2013-2017), wind speed, relative humidity and wind chill, resulting in the low value of AOD which declines from $(0.50)$ in winter to $(0.28)$ and $(0.26)$ in spring and summer months respectively, and again rise to $(0.31)$ in autumn months. It is characterized by temperature decline of nearly $8{ }^{0} \mathrm{C}$ from an average recorded air temperature of $\sim 22^{\circ} \mathrm{C}$ in summer months with atmospheric stability and dry weather 
conditions (least rainfall) prevailing in autumn months (harvesting season) attributing pollution in the atmosphere. As shown in the Fig. 2, the low PBLH which determines the environmental capacity for the dispersion of atmospheric pollutants is indicating the deteriorating air quality during winter months. Strong association was seen in the variation of different meteorological variables and the incidence of ARIs as shown in the Table 1, Fig. 2 and Fig. 3. During the winter months (January, February, November, and December), extreme dip in the air temperature, relative humidity, low wind speed, wind chill factor and high value of AOD show high cases of ARIs among the population as per the medical records (Fig. 2). During spring and summer months' cases of ARIs were recorded low as compared to winter months from 2013-2017 and again show sharp rise in autumn months in the study region. Figure 3 shows the month wise variation in the meteorological factors from 2013-2017 in the study region. 
Table 1

Monthly variations in meteorological parameters and the incidence of ARIs during 2013-2017 over study area.

\begin{tabular}{|c|c|c|c|c|c|c|c|c|c|}
\hline Years & Months & $\begin{array}{l}\text { Average } \\
\mathrm{T}\left({ }^{\circ} \mathrm{C}\right)\end{array}$ & $\begin{array}{l}\text { Wind } \\
\text { speed } \\
(\mathrm{mph})\end{array}$ & $\begin{array}{l}\text { Wind } \\
\text { chill } \\
\text { factor }\end{array}$ & $\begin{array}{l}\text { Atmospheric } \\
\text { pressure (mb) }\end{array}$ & $\begin{array}{l}\text { Relative } \\
\text { humidity } \\
\left(\mathrm{g} / \mathrm{m}^{3}\right)\end{array}$ & $\begin{array}{l}\text { Rainfall } \\
(\mathrm{mm})\end{array}$ & $A O D$ & $\begin{array}{l}\text { IR_ARIs/1K } \\
\text { population }\end{array}$ \\
\hline \multirow[t]{12}{*}{2013} & Jan & 3.2 & 1.09 & 2.9 & 8390.5 & 59 & 68.6 & 0.26 & 6.09 \\
\hline & Feb & 4.5 & 0.78 & 6 & 8380.1 & 55 & 211.7 & 0.29 & 5.7 \\
\hline & Mar & 11 & 1.61 & 9.1 & 8383.4 & 61 & 84.6 & 0.3 & 5.4 \\
\hline & Apr & 12.6 & 1.66 & 10.6 & 8357.9 & 64 & 101 & 0.35 & 4.8 \\
\hline & May & 13.7 & 1.7 & 11.7 & 8364.2 & 78 & 85.4 & 0.28 & 4.1 \\
\hline & Jun & 21.9 & 2.4 & 19 & 8300.7 & 81 & 92.4 & 0.22 & 3.6 \\
\hline & Jul & 24.4 & 1.8 & 23.1 & 8270.4 & 85 & 19.4 & 0.24 & 3.3 \\
\hline & Aug & 23.4 & 2.2 & 21.1 & 8298.5 & 63 & 153.4 & 0.3 & 5.4 \\
\hline & Sep & 20.2 & 2 & 18 & 8340 & 71 & 27.7 & 0.31 & 6 \\
\hline & Oct & 17 & 2.06 & 14.3 & 8372.7 & 62 & 26.4 & 0.31 & 6.5 \\
\hline & Nov & 8.1 & 1.73 & 5.5 & 8402.1 & 58 & 12.6 & 0.4 & 7.4 \\
\hline & Dec & 4.8 & 1.48 & 2.8 & 8376.2 & 61 & 17.5 & 0.46 & 8.3 \\
\hline \multirow[t]{12}{*}{2014} & Jan & 2.1 & 1.41 & 0.2 & 8421.6 & 56 & 52.4 & 0.22 & 7.4 \\
\hline & Feb & 4.5 & 1.78 & 1.4 & 8352.3 & 54 & 142.7 & 0.23 & 6.6 \\
\hline & Mar & 6.6 & 1.29 & 5.5 & 8372.2 & 60 & 403.7 & 0.33 & 6.9 \\
\hline & Apr & 11.9 & 1.4 & 10.8 & 8377.6 & 63 & 152.7 & 0.29 & 6.4 \\
\hline & May & 16.3 & 2.2 & 13.2 & 8354.1 & 77 & 145.6 & 0.29 & 5.9 \\
\hline & Jun & 20.5 & 2.4 & 17.4 & 8312.8 & 72 & 38.4 & 0.18 & 4.6 \\
\hline & Jul & 24.1 & 2 & 22.3 & 8293 & 81 & 45.6 & 0.3 & 4.9 \\
\hline & Aug & 22.7 & 2.12 & 20.5 & 8313 & 60 & 43.7 & 0.31 & 6.2 \\
\hline & Sep & 19 & 2 & 16.7 & 8350.3 & 69 & 156.7 & 0.29 & 7.3 \\
\hline & Oct & 14.3 & 2.2 & 11 & 8394 & 59 & 42.4 & 0.35 & 7.8 \\
\hline & Nov & 8.2 & 1.2 & 7.6 & 8404.7 & 57 & 63.7 & 0.55 & 8.9 \\
\hline & $\mathrm{Dec}$ & 4.1 & 1.6 & 1.6 & 8399.07 & 56 & 1.6 & 0.48 & 9.7 \\
\hline \multirow[t]{7}{*}{2015} & Jan & 4.5 & 0.96 & 4.9 & 8396.1 & 54 & 42 & 0.27 & 6.9 \\
\hline & Feb & 4.7 & 1.3 & 3.5 & 8385.8 & 53 & 232.6 & 0.2 & 6.5 \\
\hline & Mar & 8 & 1.2 & 7.4 & 8386.3 & 60 & 269.6 & 0.33 & 6.4 \\
\hline & Apr & 13.5 & 2 & 10.6 & 8360 & 63 & 253.6 & 0.29 & 5.3 \\
\hline & May & 16 & 3.6 & 10.2 & 8352 & 75 & 116.4 & 0.3 & 4.9 \\
\hline & Jun & 18.6 & 4 & 12.6 & 8322.9 & 69 & 92.4 & 0.19 & 4.7 \\
\hline & Jul & 23.1 & 2.9 & 19.4 & 8291.7 & 79 & 170.9 & 0.22 & 4.2 \\
\hline
\end{tabular}




\begin{tabular}{|c|c|c|c|c|c|c|c|c|c|}
\hline Years & Months & $\begin{array}{l}\text { Average } \\
\mathrm{T}\left({ }^{\circ} \mathrm{C}\right)\end{array}$ & $\begin{array}{l}\text { Wind } \\
\text { speed } \\
(\mathrm{mph})\end{array}$ & $\begin{array}{l}\text { Wind } \\
\text { chill } \\
\text { factor }\end{array}$ & $\begin{array}{l}\text { Atmospheric } \\
\text { pressure (mb) }\end{array}$ & $\begin{array}{l}\text { Relative } \\
\text { humidity } \\
\left(\mathrm{g} / \mathrm{m}^{3}\right)\end{array}$ & $\begin{array}{l}\text { Rainfall } \\
(\mathrm{mm})\end{array}$ & AOD & $\begin{array}{l}\text { IR_ARIs/1K } \\
\text { population }\end{array}$ \\
\hline & Aug & 23 & 2.5 & 20 & 8307.3 & 59 & 63.6 & 0.3 & 6.3 \\
\hline & Sep & 18.4 & 2.5 & 14.9 & 8358.1 & 64 & 65.5 & 0.27 & 6.7 \\
\hline & Oct & 14.9 & 1.9 & 12.4 & 8400.6 & 60 & 172.5 & 0.26 & 7.1 \\
\hline & Nov & 10.4 & 1.7 & 8.1 & 9214.3 & 56 & 101.1 & 0.45 & 8 \\
\hline & Dec & 4 & 1.03 & 4 & 8406.3 & 58 & 44.3 & 0.55 & 8.4 \\
\hline \multirow[t]{12}{*}{2016} & Jan & 4.1 & 1.1 & 3.8 & 8386 & 55 & 91.7 & 0.15 & 4.9 \\
\hline & Feb & 6.7 & 2 & 3.2 & 8393.7 & 54 & 54.9 & 0.21 & 4.5 \\
\hline & Mar & 9.2 & 1.8 & 6.5 & 8389.5 & 58 & 312 & 0.3 & 4.3 \\
\hline & Apr & 12.7 & 2.5 & 8.5 & 8375.6 & 62 & 102.2 & 0.27 & 3.7 \\
\hline & May & 18.3 & 3.6 & 12.8 & 8340.4 & 74 & 77.5 & 0.24 & 3.4 \\
\hline & Jun & 22.1 & 4.9 & 15.6 & 8311.1 & 73 & 23 & 0.24 & 3.1 \\
\hline & Jul & 23.4 & 5.4 & 16.6 & 8283.7 & 81 & 66.6 & 0.25 & 3 \\
\hline & Aug & 22.1 & 2.6 & 18.8 & 8307.3 & 63 & 31.6 & 0.25 & 3 \\
\hline & Sep & 20.3 & 2.2 & 17.6 & 8320.6 & 72 & 5 & 0.36 & 3.8 \\
\hline & Oct & 15.2 & 2.3 & 11.8 & 8352.3 & 63 & 3.8 & 0.29 & 5 \\
\hline & Nov & 7.9 & 3.5 & 1.1 & 8386 & 58 & 0 & 0.51 & 5.6 \\
\hline & Dec & 4.4 & 0.83 & 5.6 & 8388 & 57 & 18.5 & 0.87 & 6.5 \\
\hline \multirow[t]{12}{*}{2017} & Jan & 1.15 & 1.16 & 0.3 & 8370.2 & 57 & 234 & 0.9 & 9.3 \\
\hline & Feb & 5.2 & 1.77 & 2.2 & 8384.1 & 56 & 145.3 & 0.24 & 5.4 \\
\hline & Mar & 8.4 & 1.89 & 5.4 & 8295 & 59 & 132.1 & 0.31 & 5.4 \\
\hline & Apr & 13.4 & 2.27 & 9.9 & 8391.2 & 61 & 252.7 & 0.31 & 4.9 \\
\hline & May & 18.2 & 2.04 & 15.8 & 8370.2 & 79 & 28.2 & 0.24 & 4.4 \\
\hline & Jun & 19.7 & 1.57 & 18.7 & 8159 & 71 & 69.2 & 0.24 & 4.1 \\
\hline & Jul & 23.4 & 1.67 & 22.3 & 8330.7 & 83 & 31.5 & 0.37 & 4 \\
\hline & Aug & 23.2 & 2.08 & 21.1 & 8325.9 & 62 & 47.5 & 0.34 & 5.8 \\
\hline & Sep & 19.9 & 1.86 & 18.1 & 8357.9 & 73 & 13.5 & 0.33 & 5.9 \\
\hline & Oct & 15.0 & 1.8 & 12.9 & 8382 & 61 & 0 & 0.36 & 7.1 \\
\hline & Nov & 8.25 & 1.11 & 8.1 & 8405 & 59 & 23.9 & 0.67 & 7.8 \\
\hline & Dec & 4.07 & 1.52 & 1.9 & 8417.4 & 61 & 66.6 & 0.81 & 8.4 \\
\hline
\end{tabular}

\subsection{Source profiling of air pollution}

Monthly variation in percentage contribution to $\mathrm{PM}_{2.5}$ (black carbon, organic carbon, sulphate, dust, and sea salt) is shown in Fig. 4. High concentration of black carbon and organic carbon are seen in winter months from 2013-2017. High pollution 
level during these months is mostly attributed due to large scale burning of biomass and biofuels utilized in cooking and charcoal formation. Generally, air quality deteriorates in Kashmir valley with highest $\mathrm{PM}_{2.5}$ concentrations $\left(\sim 350 \mu \mathrm{g} / \mathrm{m}^{3}\right)$ during winter [23]. This region shows the highest concentration of black carbon among all the high altitudes observation sites in India and Nepal. A high concentration of black carbon is found in winter and autumn season mainly because of large-scale burning of biomass such as twigs and shedding leaves of plants for the formation of charcoal [42].

Figure $5(\mathrm{a}-\mathrm{c})$ shows the possible geographical potent factors contributing to the source of air pollution in the region. This study region with valley structure is surrounded by mountains from all sides, traps all the air pollutants mostly emitted from the burning of agricultural and horticulture residuals (with quantum jump seen in existing high density orchards) and vehicular emissions in the region, along with traditional source used for cooking. The perpetual backwardness in the region results into a higher dependency of households on fossil fuels and biofuels, around $78 \%$ of the total households are using the traditional source of energy for cooking such as burning of biomass fuel substances (firewood, crop residues, dry cow dung, coal and dry leaves). This is enormously contributing in the emission of pollutants BC and OC during winter [43]. Dominant horticulture activities in the region sharing $35.8 \%$ of the total horticulture land of the whole valley (JK Statistical digest 2016) also attributed to the emission of BC and OC in the lower layer of atmosphere by burning horticulture residues obtained from continuous and unavoidable process (pruning), along with shedding of leaves which is utilized in the formation of charcoal to keep orchard lands clean and protect them from pest and winter calamity. Burning of huge fire woods and dry leaves produces ample smoke mainly in the form BC and OC with least dispersion due to lower PBLH in winter months. Due to the financial schemes provided by banking sectors there has been an excessive rise in the vehicular registration in the region that can be seen as a growing concern for the emission of air pollutants in the atmosphere and making habitants of the region susceptible to inhale harmful air pollutants.

\subsection{Backward trajectory Analysis}

Figure 6 (a-d) shows the seasonal wind rose maps for 2013-2017. It shows the pattern of seasonal variation in the wind direction and wind speed. The winds mainly blow from the west, south-west, and south-eastern side throughout the year. Zainab et al, 2018 [23] has shown the role westerly winds in the contribution of high PM2.5 levels in the Kashmir valley, mainly originated mainly from Afghanistan and other surrounding areas. We have depicted the number of trajectories passing through a given area through concentrated trajectory map as shown in Fig. 7 (a-d). In the month of January (winter proxy) most of the trajectories reaching at study region are coming from the west and south direction of study area and are becoming densest in this area. The colorbar represents the number of trajectories and we can see here that the number of trajectories is highest in the southward of the study area. This is a very interesting result as a significant portion of IGP is lying in the southward area where these trajectories are densest. Since IGP is a very agriculturally active and highly commercialized area, therefore these winds may be bringing a lot of pollutants with them in the winter season.

\subsection{Statistical modeling}

We carried step wise multiple regression in SPSS version 2.0. The Pearson's correlation coefficient calculated show variables of meteorological variables negatively correlated with the incidence of ARIs, i.e. Air temperature (-0.59), winds peed (-0.54) and wind chill (-0.52), while AOD shows positive relationship with the incidence of ARIs (0.59), as shown in the Table 2 . Step wise multiple regressions carried out in this study show that the air temperature, aerosol optical depth and wind speed are strong contributing factors affecting the incidence rate of ARIs with statistically significant $p$ value $<=0.05$ as shown in the Table 3. ANOVA test (shown in the Table 4) shows a significant relation between the meteorological variables and incidence of respiratory infections with $F$ value of 31.81 for aerosol optical depth, $F(28.51)$ for AOD and air temperature, and $F(21.87)$ for AOD, air temperature and wind speed with higher degree of freedom (df) and $p$ value $<0.000$. Coefficients (standardized and unstandardized) shown in Table 5 indicates that one-unit increase in aerosol optical depth will increase the incidence of ARIs by 6.35 and one-unit increase in air temperature will decrease IR_ARIs by -0.096. Similarly, with one-unit increase in wind speed will decrease the IR_ARIs by -0.45 , which in all the cases here indicates per thousand of the population with 
statistically significant $p$ value $<0.000$. The multi collinearity statistics test carried here indicates the high normal distribution of data with variance inflation factor below 10 with least standard error.

Table 2

Correlation matrix between meteorological parameters and IR_ARIs.

\begin{tabular}{|c|c|c|c|c|c|c|c|c|}
\hline & & IR_ARIs & Avg_T & Wind_S & Wind_CF & Atmospheric_P & Rainfall_mm & Avg_AOD \\
\hline \multirow{7}{*}{$\begin{array}{l}\text { Pearson } \\
\text { Correlation }\end{array}$} & IR_ARIs & 1.000 & -.593 & -.543 & -.528 & .382 & .030 & .595 \\
\hline & Avg_T & -.593 & 1.000 & .576 & .971 & -.325 & -.247 & -.410 \\
\hline & Wind_S & -.543 & .576 & 1.000 & .381 & -.200 & -.170 & -.331 \\
\hline & Wind_CF & -.528 & .971 & .381 & 1.000 & -.323 & -.235 & -.359 \\
\hline & Atmospheric_P & .382 & -.325 & -.200 & -.323 & 1.000 & .053 & .221 \\
\hline & Rainfall_mm & .030 & -.247 & -.170 & -.235 & .053 & 1.000 & -.099 \\
\hline & Avg_AOD & .595 & -.410 & -.331 & -.359 & .221 & -.099 & 1.000 \\
\hline \multirow{7}{*}{$\begin{array}{l}\text { Sig. (1- } \\
\text { tailed) }\end{array}$} & IR_ARIs & . & .000 & .000 & .000 & .001 & .410 & .000 \\
\hline & Avg_T & .000 & . & .000 & .000 & .006 & .028 & .001 \\
\hline & Wind_S & .000 & .000 & . & .001 & .063 & .097 & .005 \\
\hline & Wind_CF & .000 & .000 & .001 & . & .006 & .035 & .002 \\
\hline & Atmospheric_P & .001 & .006 & .063 & .006 & . & .344 & .045 \\
\hline & Rainfall_mm & .410 & .028 & .097 & .035 & .344 & . & .225 \\
\hline & Avg_AOD & .000 & .001 & .005 & .002 & .045 & .225 & . \\
\hline \multirow[t]{7}{*}{$\mathrm{N}$} & IR_ARIs & 60 & 60 & 60 & 60 & 60 & 60 & 60 \\
\hline & Avg_T & 60 & 60 & 60 & 60 & 60 & 60 & 60 \\
\hline & Wind_S & 60 & 60 & 60 & 60 & 60 & 60 & 60 \\
\hline & Wind_CF & 60 & 60 & 60 & 60 & 60 & 60 & 60 \\
\hline & Atmospheric_P & 60 & 60 & 60 & 60 & 60 & 60 & 60 \\
\hline & Rainfall_mm & 60 & 60 & 60 & 60 & 60 & 60 & 60 \\
\hline & Avg_AOD & 60 & 60 & 60 & 60 & 60 & 60 & 60 \\
\hline
\end{tabular}

Table 3

Step wise multiple regression analysis between meteorological parameters \& IR_ARIs.

\begin{tabular}{|llll|}
\hline Model & $\begin{array}{l}\text { Variables } \\
\text { Entered }\end{array}$ & $\begin{array}{l}\text { Variables } \\
\text { Removed }\end{array}$ & Method \\
\hline 1 & AOD & $\cdot$ & $\begin{array}{l}\text { Stepwise (Criteria: Probability-of-F-to-enter }<=.050 \text {, Probability-of-F-to- } \\
\text { remove }>=.100) .\end{array}$ \\
\hline 2 & Avg_T & $\begin{array}{l}\text { Stepwise (Criteria: Probability-of-F-to-enter }<=.050 \text {, Probability-of-F-to- } \\
\text { remove }>=.100) .\end{array}$ \\
\hline 3 & Wind_s & $\begin{array}{l}\text { Stepwise }(\text { Criteria: Probability-of-F-to-enter }<=.050 \text {, Probability-of-F-to- } \\
\text { remove }>=.100) .\end{array}$ \\
\hline a. Dependent Variable: IR_ARls & \\
\hline
\end{tabular}


Table 4

Analysis of variance (ANOVA) of meteorological parameters and IR_ARIs

\begin{tabular}{|c|c|c|c|c|c|c|}
\hline \multicolumn{2}{|c|}{ Model } & \multirow{2}{*}{$\begin{array}{l}\text { Sum of Squares } \\
57.112\end{array}$} & \multirow{2}{*}{$\begin{array}{l}\text { df } \\
1\end{array}$} & \multirow{2}{*}{$\begin{array}{l}\text { Mean Square } \\
57.112\end{array}$} & \multirow{2}{*}{$\begin{array}{l}\mathbf{F} \\
31.816\end{array}$} & \multirow{2}{*}{$\begin{array}{l}\text { Sig. } \\
.000^{\mathrm{b}}\end{array}$} \\
\hline 1 & Regression & & & & & \\
\hline & Residual & 104.112 & 58 & 1.795 & & \\
\hline & Total & 161.224 & 59 & & & \\
\hline \multirow[t]{3}{*}{2} & Regression & 80.634 & 2 & 40.317 & \multirow[t]{2}{*}{28.516} & \multirow[t]{3}{*}{$.000^{\mathrm{c}}$} \\
\hline & Residual & 80.590 & 57 & 1.414 & & \\
\hline & Total & 161.224 & 59 & & & \\
\hline \multirow[t]{3}{*}{3} & Regression & 86.999 & 3 & 29.000 & \multirow[t]{2}{*}{21.879} & \multirow[t]{3}{*}{$.000^{\mathrm{d}}$} \\
\hline & Residual & 74.225 & 56 & 1.325 & & \\
\hline & Total & 161.224 & 59 & & & \\
\hline \multicolumn{7}{|c|}{ a. Dependent Variable: IR_ARIs } \\
\hline \multicolumn{7}{|c|}{ b. Predictors: (Constant), AOD } \\
\hline \multicolumn{7}{|c|}{ c. Predictors: (Constant), AOD, Avg_T } \\
\hline \multicolumn{7}{|c|}{ d. Predictors: (Constant), AOD, Avg_T, Wind_s } \\
\hline
\end{tabular}

Table 5

Coefficients of meteorological parameters and IR_ARIs.

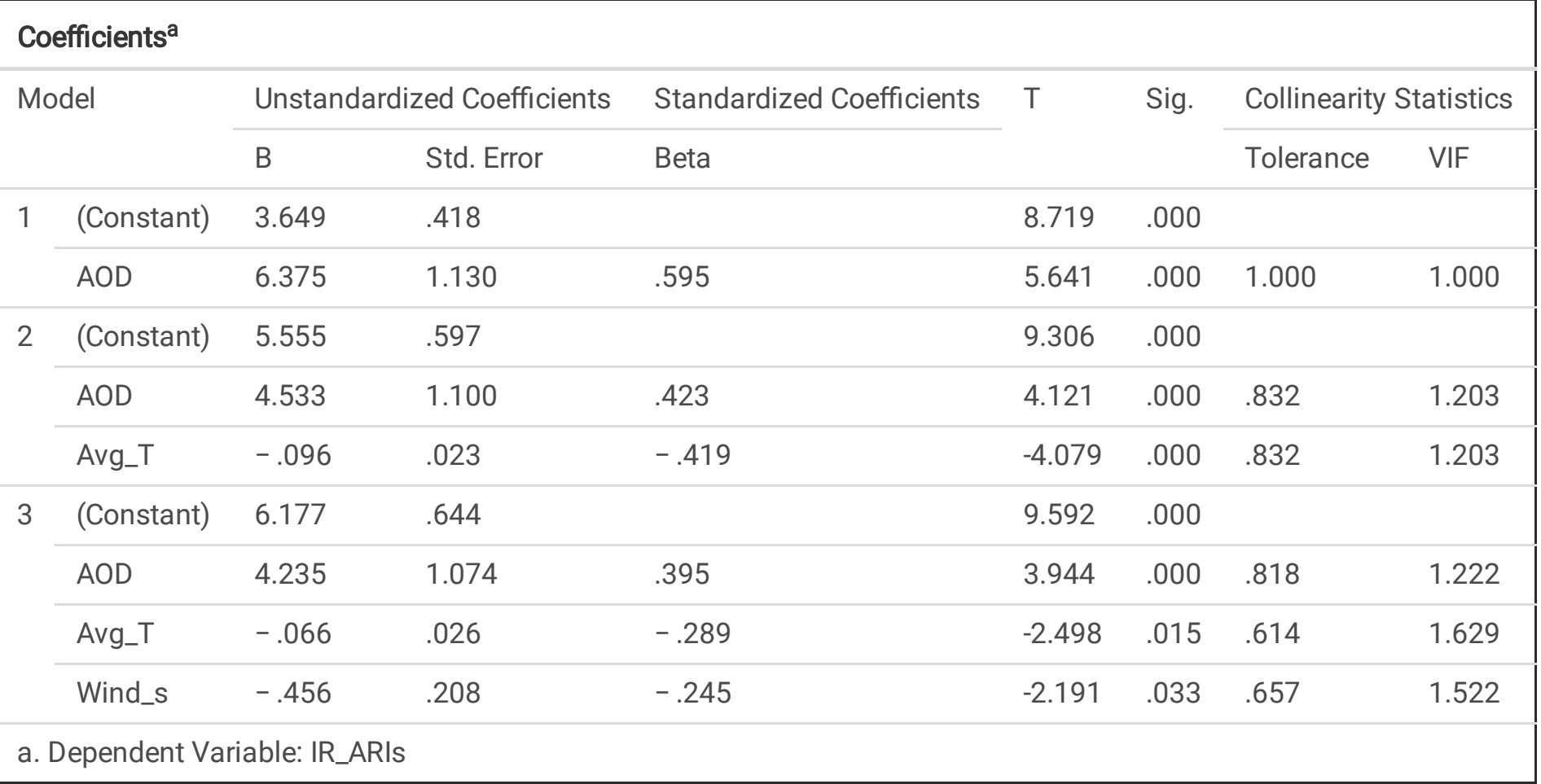

\subsection{Limitations}

The study highlights the role of different meteorological parameters in the incidence of respiratory infections identifying potent causes and source of different air pollutants in the study region. The study also pointed out the possible contribution of IGP in bringing the air pollutants to the valley which is quite significant. The main limitation of the study to worth mention here is non estimation of the proportion of particulate matter in the atmosphere in different seasons due to non-availability 
of such data in the region that would have surely boosted this work more. There is also a need to find the source of aerosol particle in the region in order to quantify the contribution of IGP in bringing pollutants to the valley. Also the correlation of meteorological variables with ARIs is found to be pathogen dependent in some studies. In future studies we can also include the pathogen specific casualties on respiratory health and correlate it with different meteorological variables.

\section{Conclusions}

The main findings of the study are that seasonal fluctuations in the meteorological variables (air temperature, wind speed and direction, wind chill factor, aerosol optical depth, and $\mathrm{PM}_{2.5}$ ) are strongly associated with the seasonal incidence of ARIs in the Himalayan region. We found high contribution of black carbon, organic carbon, and sulphate to total $\mathrm{PM}_{2.5}$ during autumn and winter months. Source of the pollutants can be attributed to both local and exotic sources. Local factors include burning of biomass and biofuels for cooking and other purpose, formation of charcoal from horticulture, crop residues and quantum rise in the transport sector in a region with no major industrial set up. The exotic sources of pollutants are mainly by long range transport by the westerly winds that brings huge junk of air pollutants from west neighbouring countries as discussed in the study (nearly $87 \%$ of winds blow from west throughout the year). The concentrated weighted wind trajectories analysis confirmed that winds before entering the valley deflects south-ward and enters in vast IGP where air mass is laden with high concentrated pollutants and gets departed towards the longitudinal depression valley, where it gets trapped. Finding the cause and mechanism behind such deflection will be a very useful and significant study for not just understanding the climate and atmospheric circulation but also for making more effective health policies. With low PBLH during winter air pollutants mostly remain near the surface with least dispersion. Habitants of the study region gets exposed to these harmful air pollutants, as seen through medical records (high cases of ARIs were seen in winter and autumn months). Strong association was seen between different meteorological variables and incidence of acute respiratory infections in the study, most dominantly in the seasonal variation of air temperature, wind speed and AOD. The air coming from polluted IGP may also bring pollutants and contribute to respiratory health problems in winters.

The study recommends that pollution control board of the state must take the urgent initiative to install particulate matter detecting analyzer in order to continuously monitor the pollution data that will be benefited to carry more in-depth research and possible conclusion. The government also needs to raise the concern and must promote eco-friendly methods for disposal of horticulture produce (charcoal making etc.) especially when the growth of horticulture in the entire valley is going to see a quantum jump due to the subsidized introduction of high-density apples in the valley, at the same time, the growth of vehicles is increasing exponentially in the state which adds to the emissions due to the combustion of fossil fuels.

\section{Declarations}

\section{Availability of data and materials}

Meteorological data are provided by the Indian Meteorological Department (IMD Srinagar; https://mausam.imd.gov.in/). MERRA-2 can be downloaded from https://gmao.gsfc.nasa.gov/reanalysis/MERRA-2/data_access/. Aerosol optical depth (AOD) from MODIS can be obtained from https://ladsweb.modaps.eosdis.nasa.gov/. Monthly data related to acute respiratory infections (ARIs) were obtained from integrated disease surveillance program (IDSP) under ministry of health, government of India.

\section{Competing interests}

The authors declare that there is no conflict of interest.

\section{Funding}

There is no funding available for this work. 


\section{Authors' contributions}

MAW and AKM have designed the work. MAW, MA, and AKM collected the required data. Data analysis and interpretation is done by AKM, MAV, and SS. AKM, MAW, and IAM drafted the manuscript.

\section{Acknowledgement}

Authors are thankful and offer sincere gratitude to the department of Integrated disease surveillance program (IDSP), Ministry of Health-GOI, IMD Srinagar for providing necessary data to carry out this work. Authors would also like to thank MODIS and MERRA-2 team members.

\section{References}

1. Stafoggia, M.; Johansson, C.; Glantz, P.; Renzi, M.;Shtein, A.; Hoogh, K.;Kloog, I.; Davoli, M.; Michelozzi, P.; Bellender, T. A random forest approach to estimate daily particulate matter, Nitrogen dioxide, and Ozone at fine spatial resolution in Swedan. Atmosphere 2020, 11, 239; doi:10.3390/atmos11030239.

2. Ghorani, A. A.; Riahi, Z. B.; Balali, M.M. Effects of air pollution on human health and practical measures for prevention in in Iran. Journal of research in medical sciences, 2016, 21:65.

3. Mohanraj, R.; Azeez, P. Health effects of airborne particulate matter and the Indian scenario. Current Science 2004, 87(6).

4. Brook, R.D.; Rajagopalan, S.; Pope, C.A., Ill; Brook, J.R.; Bhatnagar, A.; Diez-Roux, A.V.; Holguin, F.; Hong, Y.; Luepker, R.V.; Mittleman, M.A.; et al. Particulate matter air pollution and cardiovascular disease: An update to the scientific statement from the American Heart Association. Circulation 2010, 121, 2331-2378.

5. Olstrup, H.; Johansson, C.; Forsberg, B.; Tornevi, A.; Ekebom, A.; Meister, K. A multi-pollutant air quality health index (AQHI) based on short-term respiratory e_ects in Stockholm, Sweden. Int. J. Environ. Res. Pub. Health 2019, 16, 105.

6. Cathryn, T. A call for the epidemiology where the pollution is: The lancet Planetary health, Comment 2017, 1(9): 355356.

7. Faustini, A.; Rapp, R.; Forastiere, F. Nitrogen dioxide and mortality: Review and meta-analysis of long-term studies. Eur. Respir. J. 2014, 44, 744-753.

8. Victor, A. U.; Akaninyene, O.; Henry, O.; Emmanuel, E. The pattern of respiratory diseases morbidity and mortality in a tertiary hospital in southern-eastern Nigeria. Pulmonary medicine, Hindawi Publishing Corporation 2013.

9. Tayde, P.; Kumar, S. Chronic obstructive pulmonary diseases in the elderly: evaluation and management. Asian J Gerontol Geriatr 2013,8:90-7.

10. Wani, M.A.; Wani, D.M.; Naik, S.; Mayer, I.A. Geographical vulnerability to respiratory infections using GIS techniquemicro analysis study in the Himalayan region- India. GeoJournal 2020. 85(5), https://doi.org/10.1007/s10708-02010307-z.

11. Gordon, T.; Balakrishnan, K.; Dey, S.; Rajagopalan, S.; Thornburg, J.; Thurston, G.; Salvi, S. Air pollution health research priorities for India: Perspectives of the Indo-US Communities of Researchers. Environment international2018, 119, 100.

12. Cui, B.; Zhang, D.; Pan, H.; Zhang, F.; Farrar, J.; Law, F.; Ba-Thein, W. Viral aetiology of acute respiratory infections among children and associated meteorological factors in southern China. BMC infectious diseases 2015, 15(1), 124.

13. Shrestha, S. L.; Shrestha, I. L.; Shrestha, N. Region-wise Effects of Climate Sensitive Variables on Some Specific Disease Burdens in Nepal. The Open Atmospheric Science Journal 2016, 10(1).

14. Darniot, M.; Pitoiset, C.; Millière, L.; Aho-Glélé, L. S.; Florentin, E.; Bour, J. B.; Manoha, C. Different meteorological parameters influence Metapneumovirus and respiratory syncytial virus activity. 2018, Journal of Clinical Virology, 104, 77-82. 
15. Rachel, W.; Angie, B.; Catriona, C.; Anna, C. Minimum home temperature threshold for health in winter- A systematic Literature review, Public Health England, 2014, 2014423.

16. Caroline, T. R.; Martin, J.S.; Harry, H.; Diederick, E. G.; Johan, P. M.; Michael, G. M. Seasonal variation in cause- specific mortality: are their high risk groups? 25 year follow up of civil servants from the first Whitehall study: International epidemiology association 2001,30, 1109-1116.

17. Mourtzoukou, E. G.; Falagas, M. E. Exposure to cold and respiratory tract infections. Int J Tuberc Lungs Dis 2007, 11(9), 938-943.

18. Ariane, A. P.; France, L.; Audrey, S.; Patrice, D.; Marc, A. B.; Charles, G.; Joseph, Z. Impact of climatic change on occupational health and safety: Studies and research projects 2013. Irsst, ISSN- 08208395.

19. Michal, A. The population of Himalayan regions by the numbers: past, present and future. Contemporary studies in environment and tourism. Cambridge scholars publishing 2017.

20. Prakash, C.T.; Abhinav, T.; Bhagwati, J. Urban growth in Himalaya: Understanding the process and options for sustainable development. Journal of urban and regional studies on contemporary India2018, 4(2): 15-27.

21. Rita, S. Impact on human health of climate and land use changes in the Hindu Kush Himalayan region. Mountain research and development (MRD), BioOne; 2019, 32(4):480-486.

22. Wani, M.A.; Kawoosa, W; Mayer, I.A Mapping of morbidity pattern of respiratory diseases: medical block analysis in the northern belt of India. GeoJournal 2019. https://doi.org/10.1007/s10708-019-10065-7.

23. Zainab, Q.H.; Gufran, B.; Srinivas, R.; Shakil, A.R.; Irfan, R. Winter burst of pristine Kashmir Valley Air. Scientific Reports. Nature.com 2018, 8:3329, DOI: 10.1038/s41598-018-20601-z.

24. Sharma, N. L.; Kuniyal, J. C.; Singh, M.; Sharma, P.; Chand, K.; Negi, A. K.; Thakur, H. K. Atmospheric ultrafine aerosol number concentration and its correlation with vehicular flow at two sites in the western Himalayan region. Kullu-Manali, India. Journal of earth system science 2011, 120(2), 281-290.

25. Farhad, M. Room temperature and airborne disease transmission. The American Society for Health Care Engineering (ASHE) 2013), 3124223800.

26. Ravindra, K.; Singh, T.; Mor, S.; Singh, V.; Mandal, T. K.; Bhatti, M. S.; Beig, G. Real-time monitoring of air pollutants in seven cities of North India during crop residue burning and their relationship with meteorology and transboundary movement of air. Science of the total environment, 2019, 690, 717-729.

27. Maji, S.; Ghosh, S.; Ahmed, S. Association of air quality with respiratory and cardiovascular morbidity rate in Delhi, India. International journal of environmental health research 2018, 28(5), 471-490.

28. Shrestha, U. B.; Gautam, S.; Bawa, K. S. Widespread climate change in the Himalayas and associated changes in local ecosystems. PloS one 2012, 7(5), e36741.

29. Deepa, M.; Rajalakshmi, M.; Nedunchezhian, R. Impact of Air Pollution on Respiratory Diseases: Correlation and Classification by Multivariate Data Analysis. Data-Enabled Discovery and Applications 2017), 1(1), 3.

30. Chen, Z.; Zhu, Y.; Wang, Y.; Zhou, W.; Yan, Y.; Zhu, C.; Ji, W. Association of meteorological factors with childhood viral acute respiratory infections in subtropical China: an analysis over 11 years. Archives of virology 2014, 159(4), 631-639.

31. Mäkinen, T.M.; Juvonen, R.; Jokelainen, J.; Harju, T. H.; Peitso, A.; Bloigu, A.; Hassi, J. Cold temperature and low humidity are associated with increased occurrence of respiratory tract infections. Respiratory medicine 2009, 103(3), 456-462.

32. Yu Shi.; Fei,H.; Zhisheng, X.; Guangqiang, F.; Zhe, Z. Comparison of four different types of planetary boundary layer heights during haze episode in Beijing. Science of the total environment. 2019, 711 (2020),

doi.org/10.1016jj.scjtotemv.2019.134928.

33. Tanveer, A. Wind chill effects in cold climate. Faculty of natural science and technology; UiT- The Artic University of Norway 2016.

34. Buchard, V., Randles, C. A., Da Silva, A. M., Darmenov, A., Colarco, P. R., Govindaraju,R., ... Yu, H. The MERRA-2 aerosol reanalysis, 1980 onward. Part II: Evaluation and case studies. Journal of Climate, 2017, 30(17), 6851-6872. 
35. Navinya, C. D., Vinoj, V., \& Pandey, S. K. Evaluation of PM2. 5 Surface Concentrations Simulated by NASA's MERRA Version 2 Aerosol Reanalysis over India and its Relation to the Air Quality Index. Aerosol and Air Quality Research, 2020, 20, 1329-1339.

36. Levy, R. C., Mattoo, S., Munchak, L. A., Remer, L. A., Sayer, A. M., Patadia, F., \& Hsu, N. C. The Collection 6 MODIS aerosol products over land and ocean. Atmospheric Measurement Techniques, 2013, 6(11), 2989.

37. Guleria, R. P., Kuniyal, J. C., Rawat, P. S., Thakur, H. K., Sharma, M., Sharma, N.L., ... Singh, M. Validation of MODIS retrieval aerosol optical depth and an investigation of aerosol transport over Mohal in north western Indian Himalaya. International journal of remote sensing, 2012, 33(17), 5379-5401.

38. Draxler, R. R., \& Rolph, G. D. HYSPLIT (HYbrid Single-Particle Lagrangian Integrated Trajectory) model access via NOAA ARL READY website (http://ready. arl. noaa. gov/HYSPLIT. php). 2010, NOAA Air Resources Laboratory. Silver Spring, MD, 25.

39. Rolph, G.; Stein, A.; Stunder, B.; Real-time Environmental Applications and Display system: READY. Environmental Modelling \& Software 2017, 95, 210-228, https://doi.org/10.1016/j.envsoft. 2017.06.025

40. Marlies, N.; Friedo, W. D.; Carmine, Z.; Kitty, J. J. Measures of diseases frequency: prevalence and incidence. Kidney disease and population health. Nephron Clin Pract 2010; 115, 17-20.

41. Yonglin, L.; Juan, L.; Fenglian, C.; Bilal, H.S.; Qing, W.; Fuyong, J.; Yanmei, Q. Yanhua, S.; Impact of meteorological factors on lower respiratory tract infection in children. International medical Research 2017, 44(1), 30-41.

42. Mudasir, A.B.; Shakil, A.R.; Gufran, B. Aerosol black carbon at an urban site-Srinagar, northwestern Himalaya, India: seasonality, sources, meteorology, and radiative forcing. Atmospheric Environment 2017, 165, 336-348.

43. Wani, M.A.; Wani, D.M.; Naik, S.; Mayer, I.A. Geographical vulnerability to respiratory infections using GIS techniquemicro analysis study in the Himalayan region- India. GeoJournal 2020. 85(5), https://doi.org/10.1007/s10708-02010307-z.

\section{Figures}




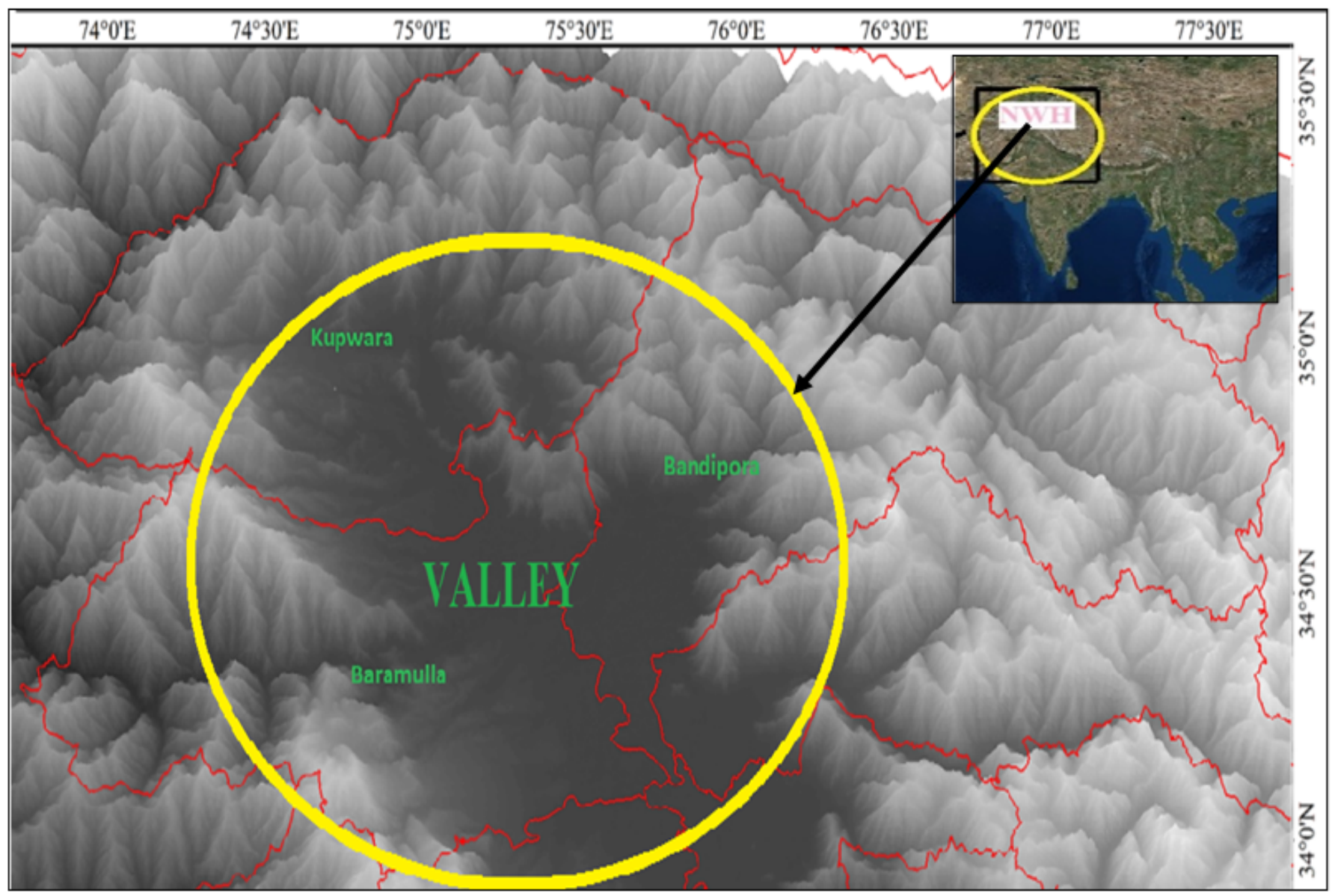

\section{Figure 1}

Map of the study area. Note: The designations employed and the presentation of the material on this map do not imply the expression of any opinion whatsoever on the part of Research Square concerning the legal status of any country, territory, city or area or of its authorities, or concerning the delimitation of its frontiers or boundaries. This map has been provided by the authors. 


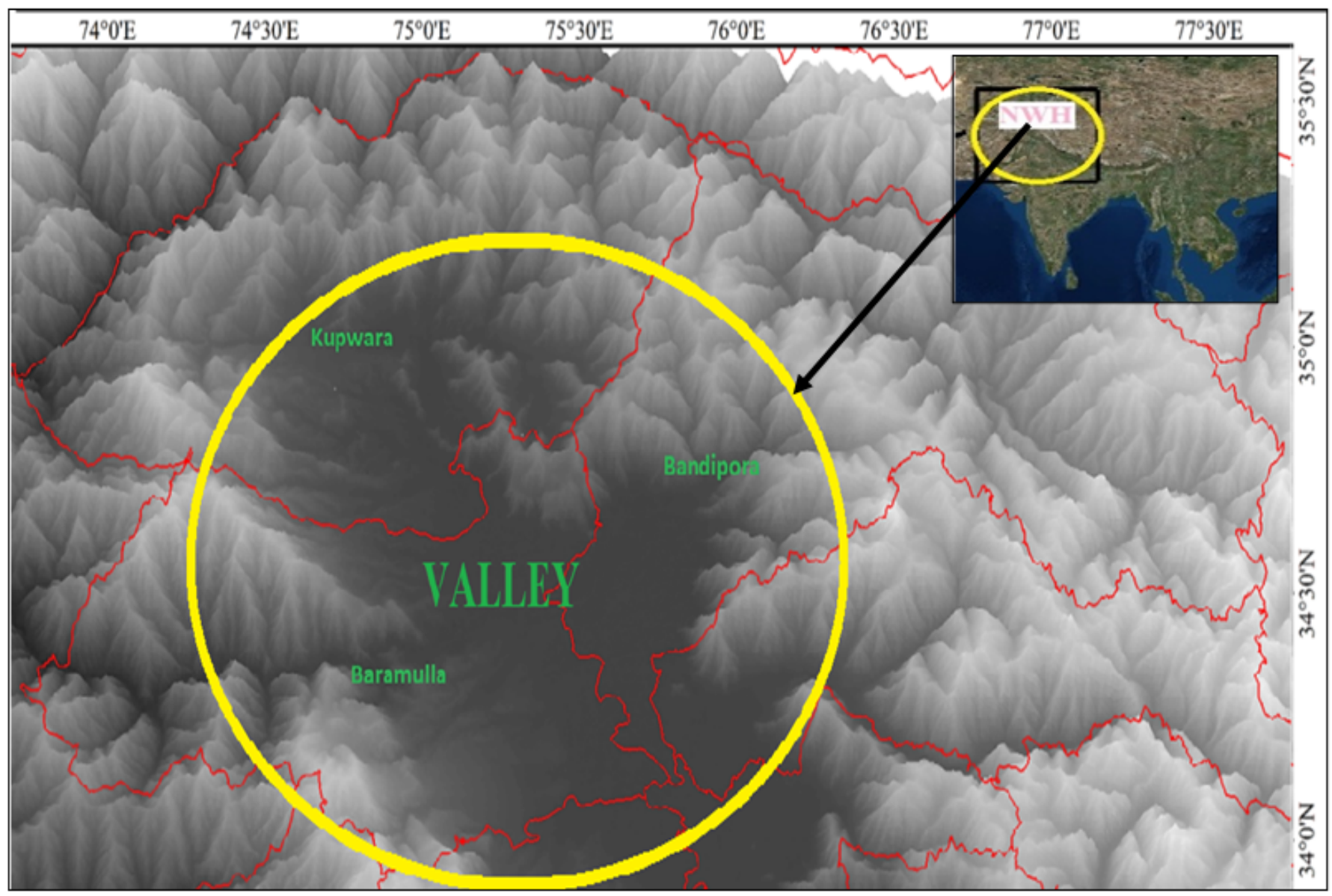

\section{Figure 1}

Map of the study area. Note: The designations employed and the presentation of the material on this map do not imply the expression of any opinion whatsoever on the part of Research Square concerning the legal status of any country, territory, city or area or of its authorities, or concerning the delimitation of its frontiers or boundaries. This map has been provided by the authors. 

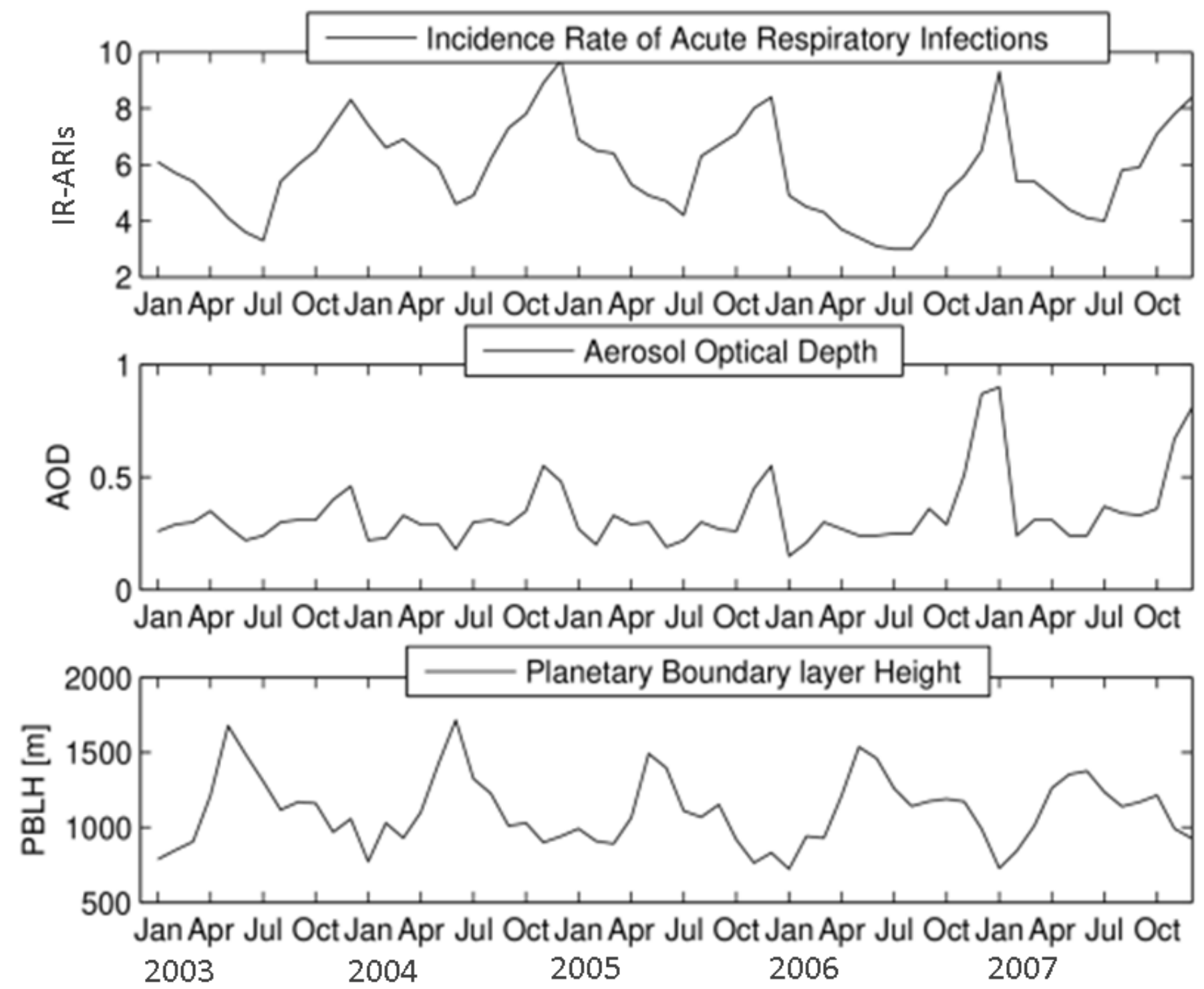

Figure 2

Monthly variations of incidence of acute respiratory infections (IR-AIRs), aerosol optical depth (AOD) and planetary boundary layer height (PBLH) during 2013-2017. 

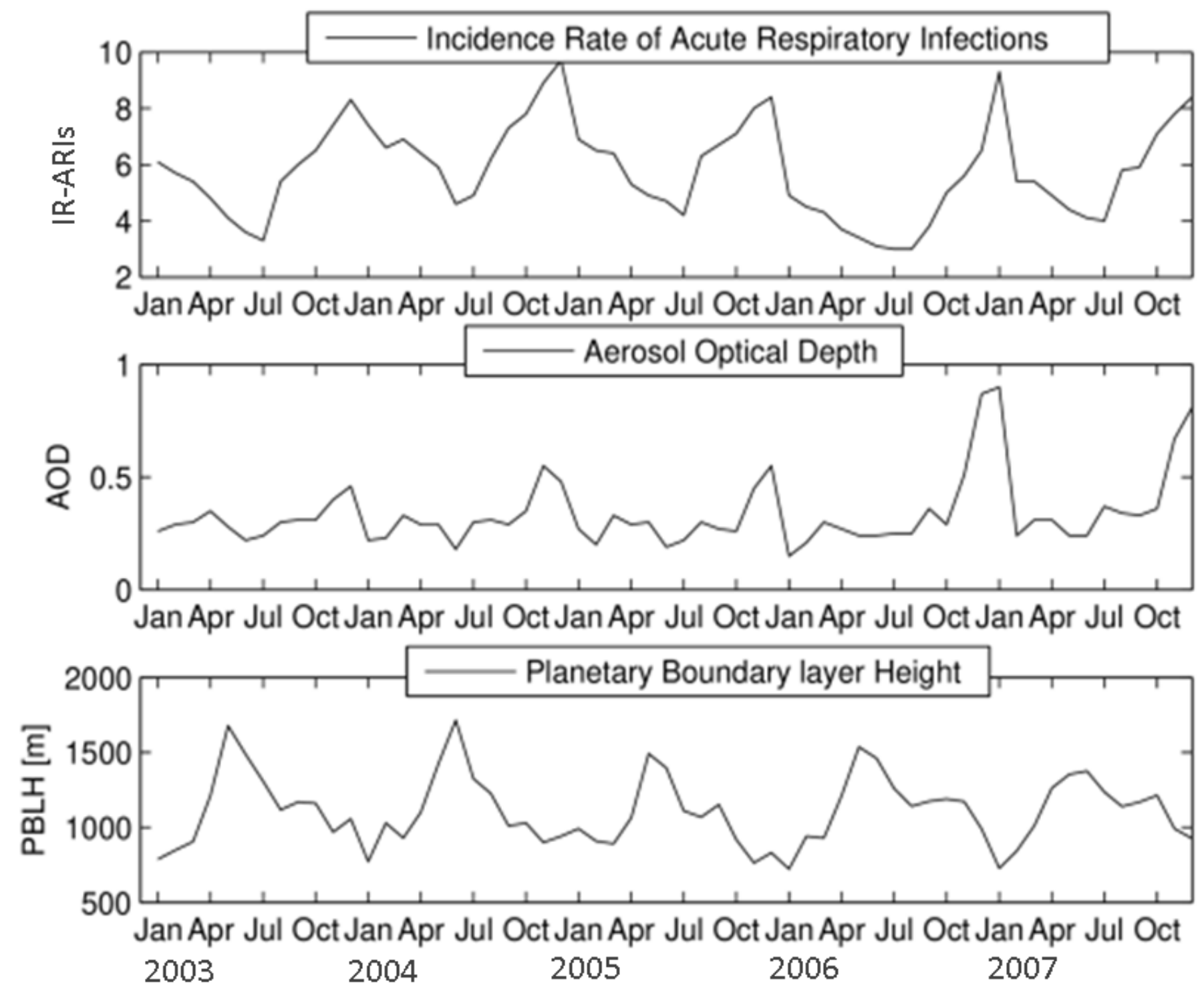

Figure 2

Monthly variations of incidence of acute respiratory infections (IR-AIRs), aerosol optical depth (AOD) and planetary boundary layer height (PBLH) during 2013-2017. 


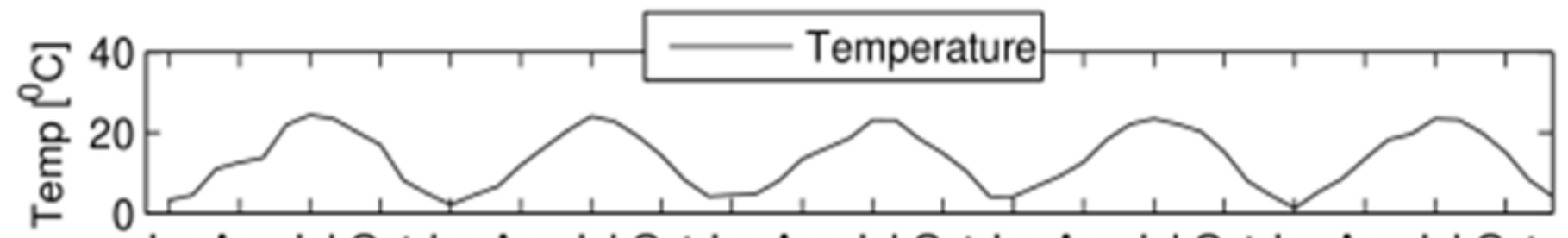

Jan Apr Jul Oct Jan Apr Jul Oct JanAor Jul Oct Jan Apr Jul Oct Jan Apr Jul Oct

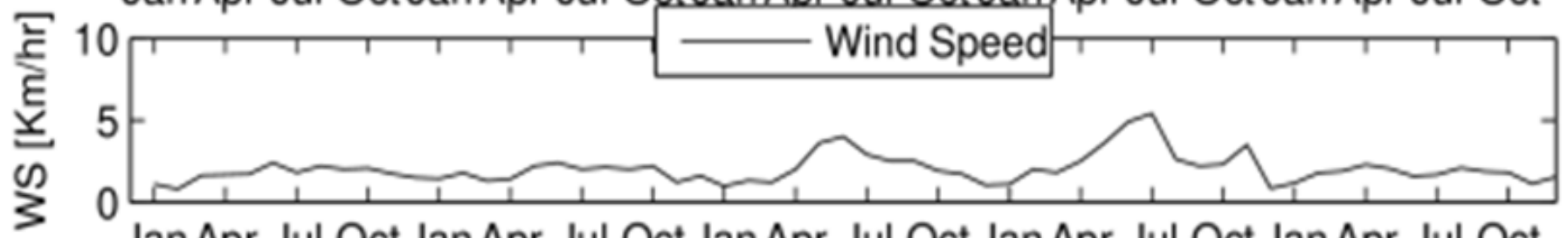

> Jan Apr Jul Oct Jan Apr Jul Oct Jan Apr Jul Oct Jan Apr Jul Oct Jan Apr Jul Oct
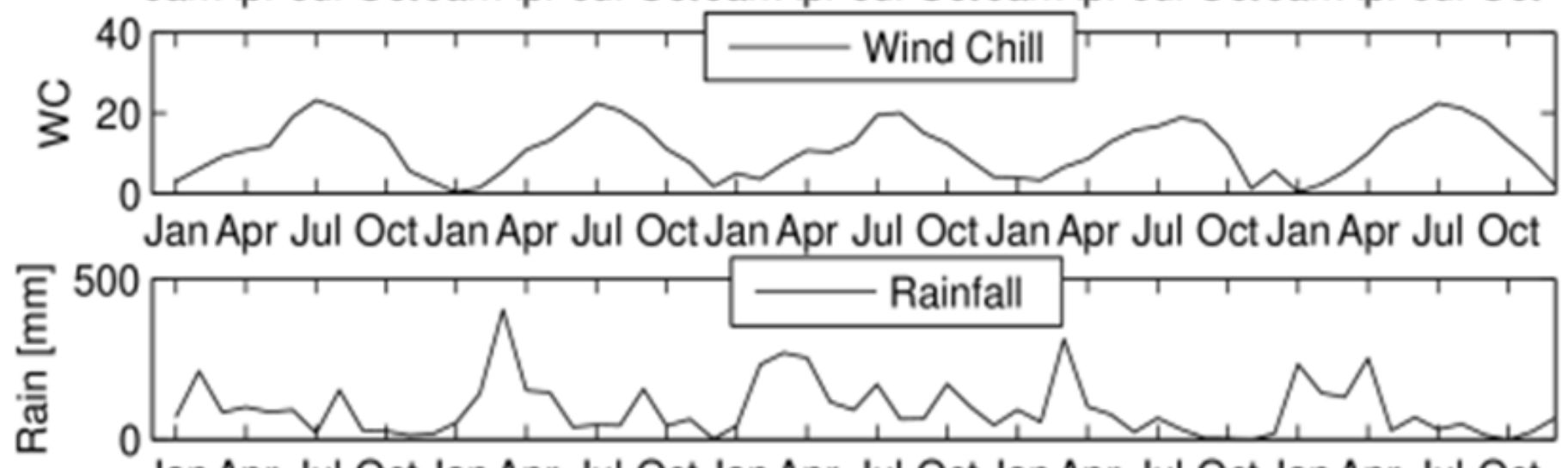

Jan Apr Jul Oct Jan Apr Jul Oct Jan Apr Jul Oct Jan Apr Jul Oct Jan Apr Jul Oct

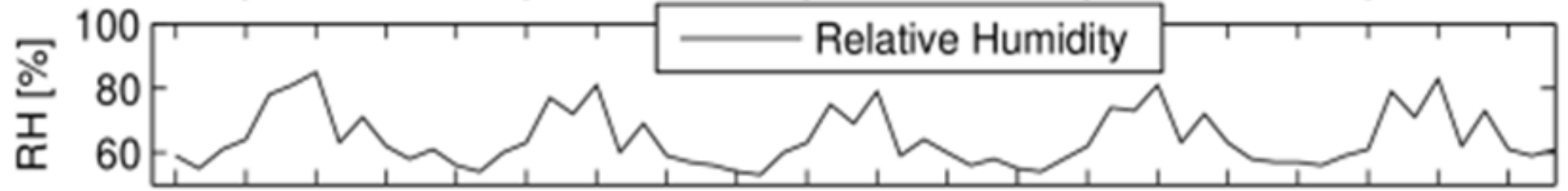

Jan Apr Jul Oct Jan Apr Jul Oct Jan Apr Jul Oct Jan Apr Jul Oct Jan Apr Jul Oct 2003 2004 2005 2006 2007

Figure 3

Monthly variations of meteorological parameters (Temperature, Wind Speed, Wind Chill, Rainfall, Relative Humidity) during 2013-2017. 


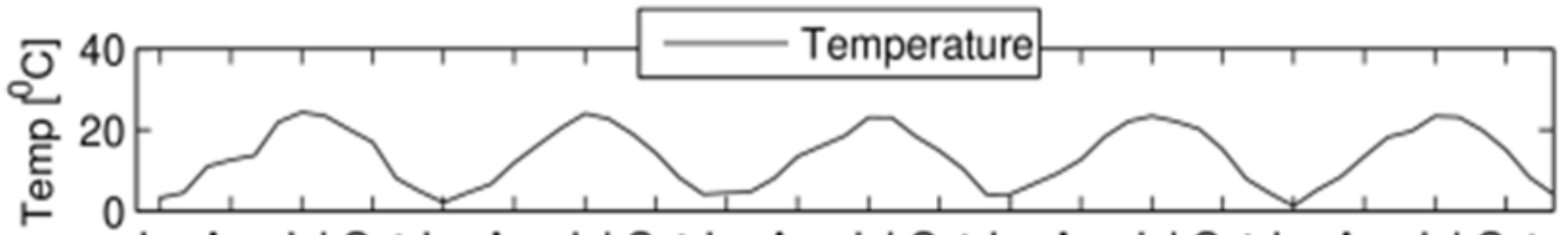

Jan Apr Jul Oct Jan Apr Jul Oct JanAor Jul Oct JanApr Jul Oct Jan Apr Jul Oct

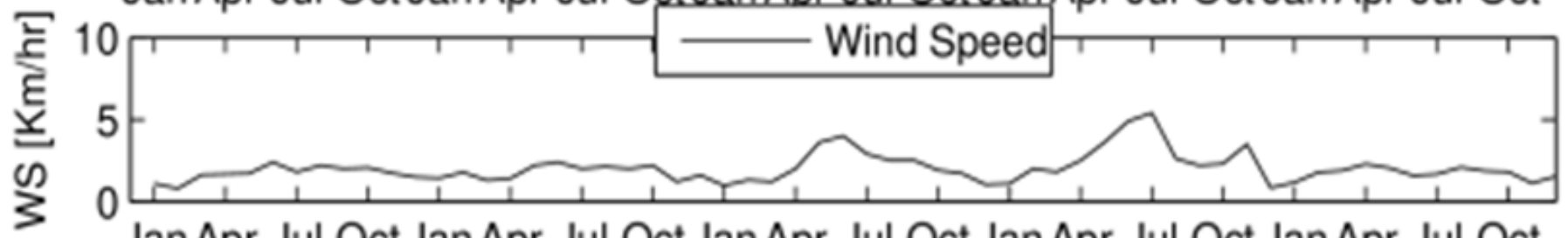

\$ Jan Apr Jul Oct Jan Apr Jul Oct Jan Apr Jul Oct Jan Apr Jul Oct Jan Apr Jul Oct
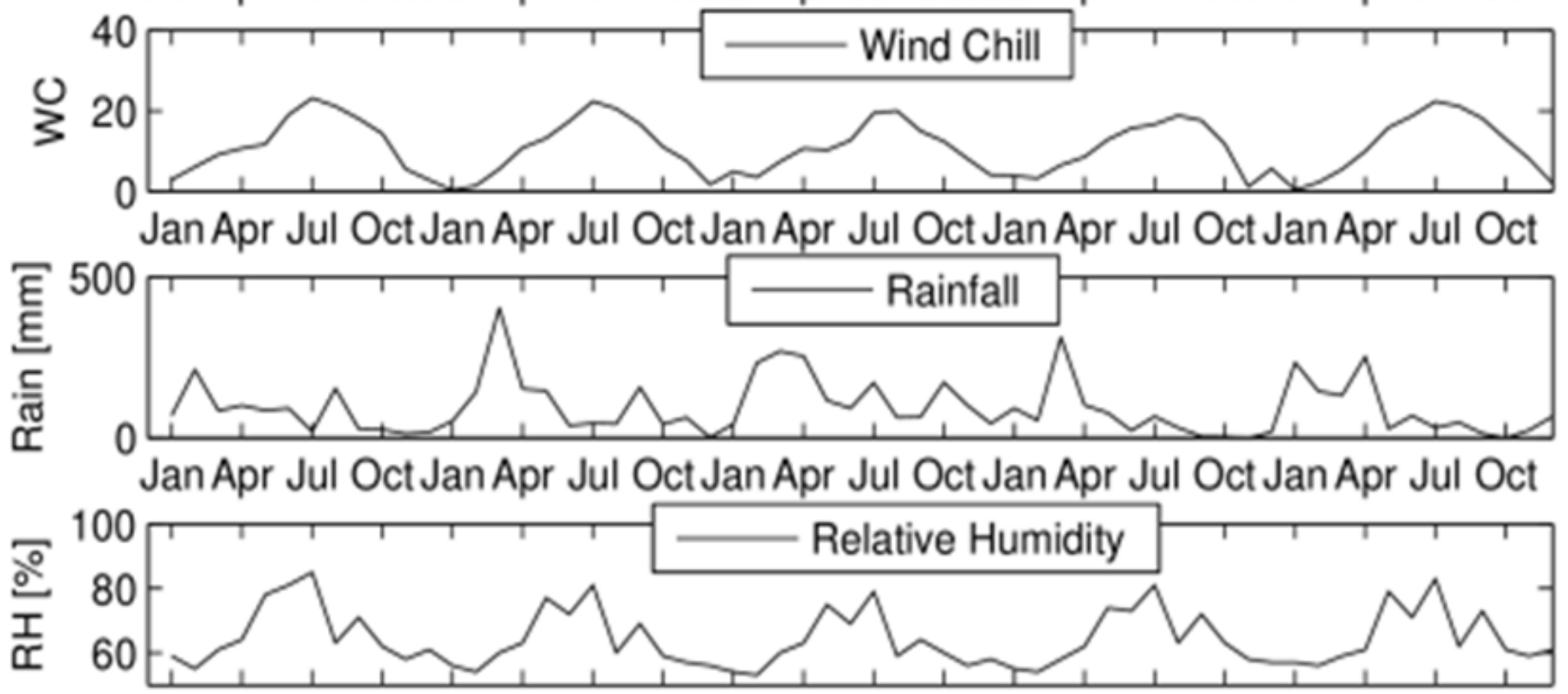

Jan Apr Jul Oct Jan Apr Jul Oct Jan Apr Jul Oct Jan Apr Jul Oct Jan Apr Jul Oct 2003 2004 2005 2006 2007

Figure 3

Monthly variations of meteorological parameters (Temperature, Wind Speed, Wind Chill, Rainfall, Relative Humidity) during 2013-2017.

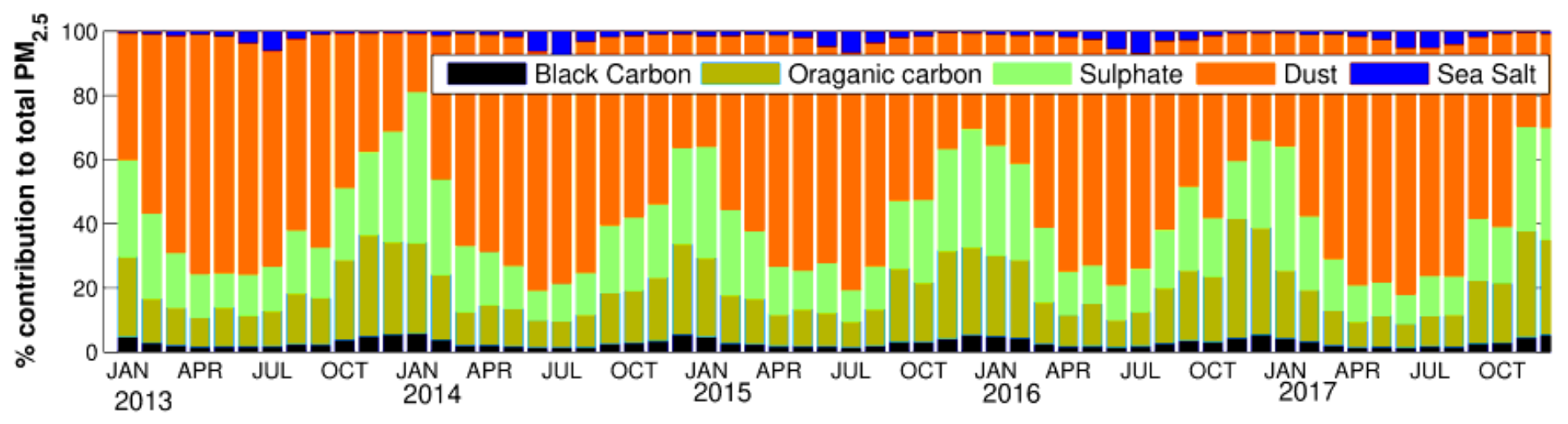

Figure 4 
Monthly variation of percentage contribution to total PM2.5 [ black carbon, organic carbon, sulphate, dust and sea salt] during 2013-2017.

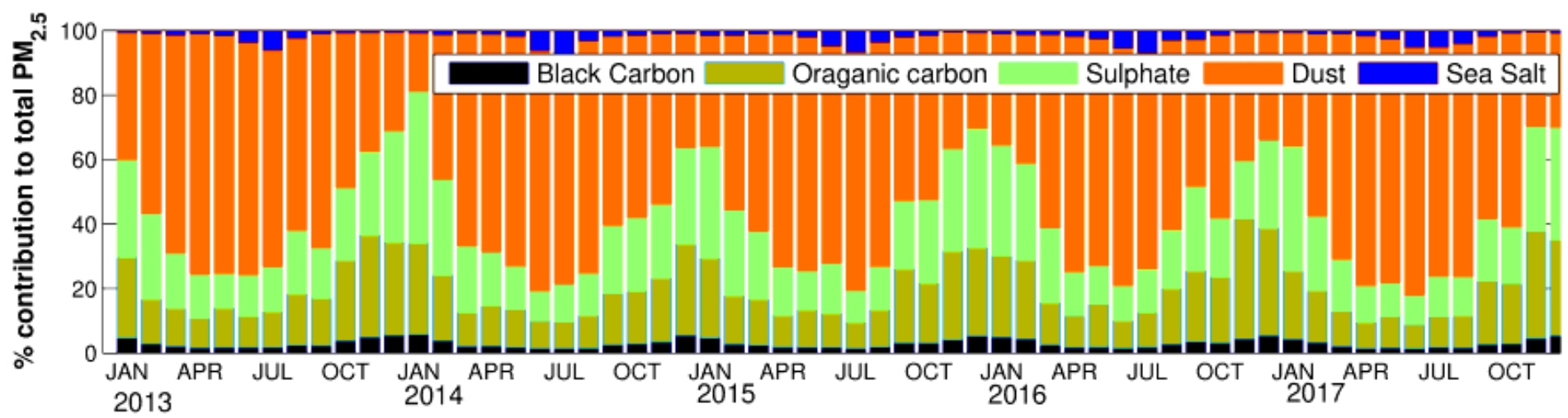

Figure 4

Monthly variation of percentage contribution to total PM2.5 [ black carbon, organic carbon, sulphate, dust and sea salt] during 2013-2017.

(a)

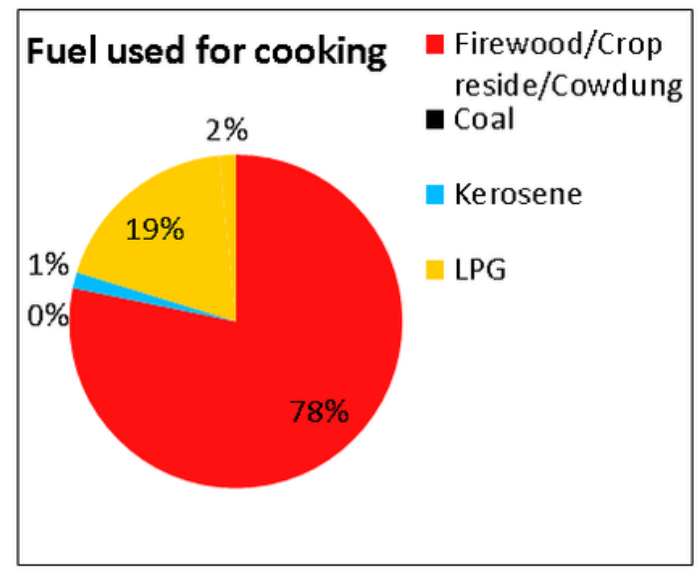

(b)

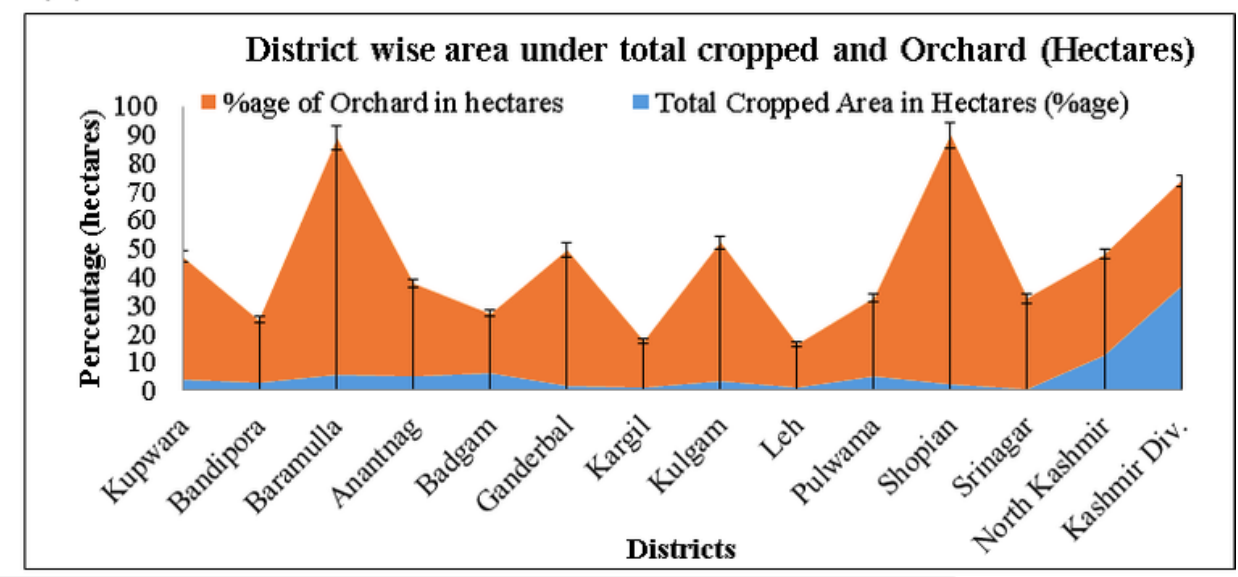

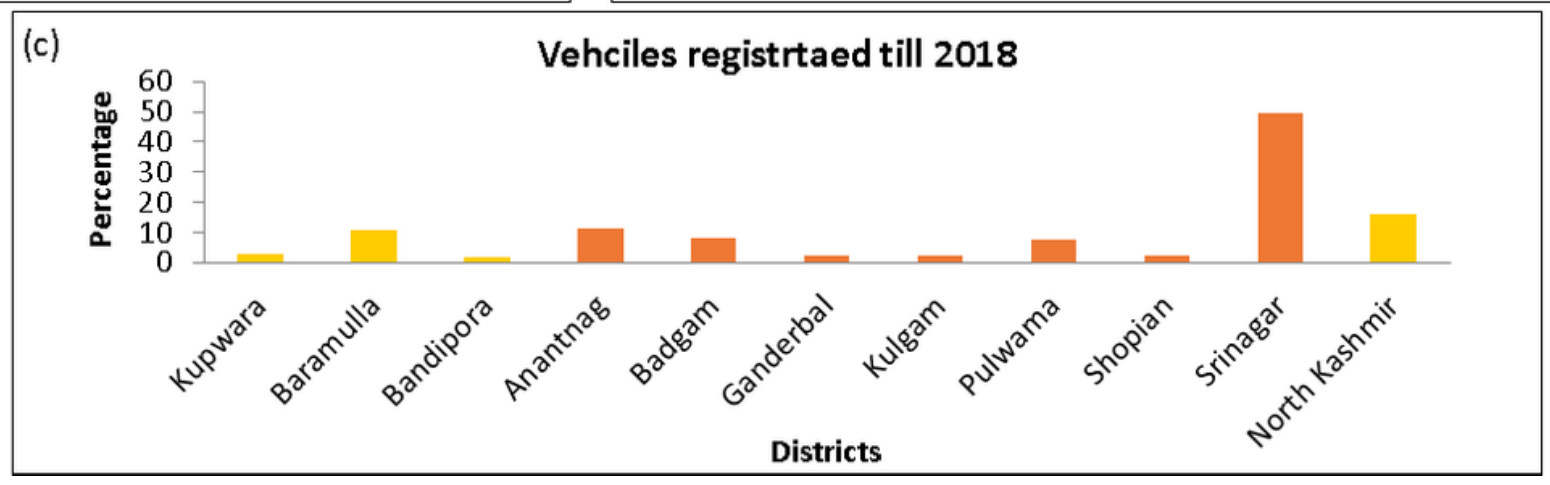

Figure 5

(a-c) Local source of air pollution (Fuel used for cooking, Horticulture residues and transport pressure). Source: Census of India 2011, JK Statistical Digest 2016, JK transport 2018. 
(a)

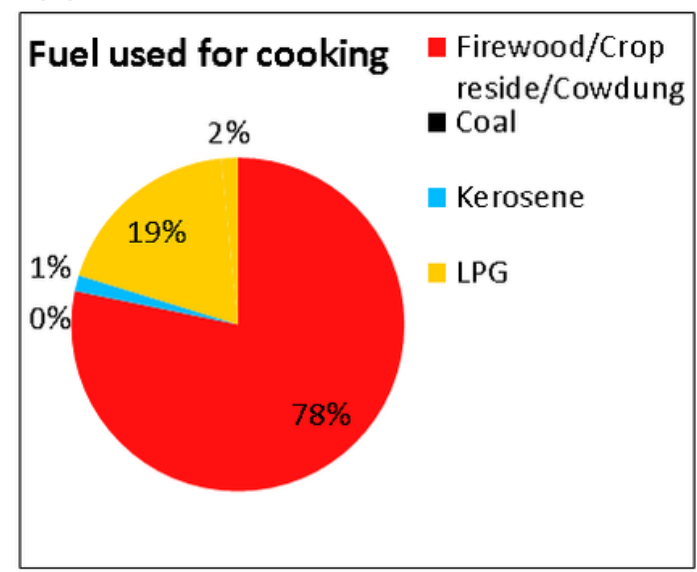

(b)

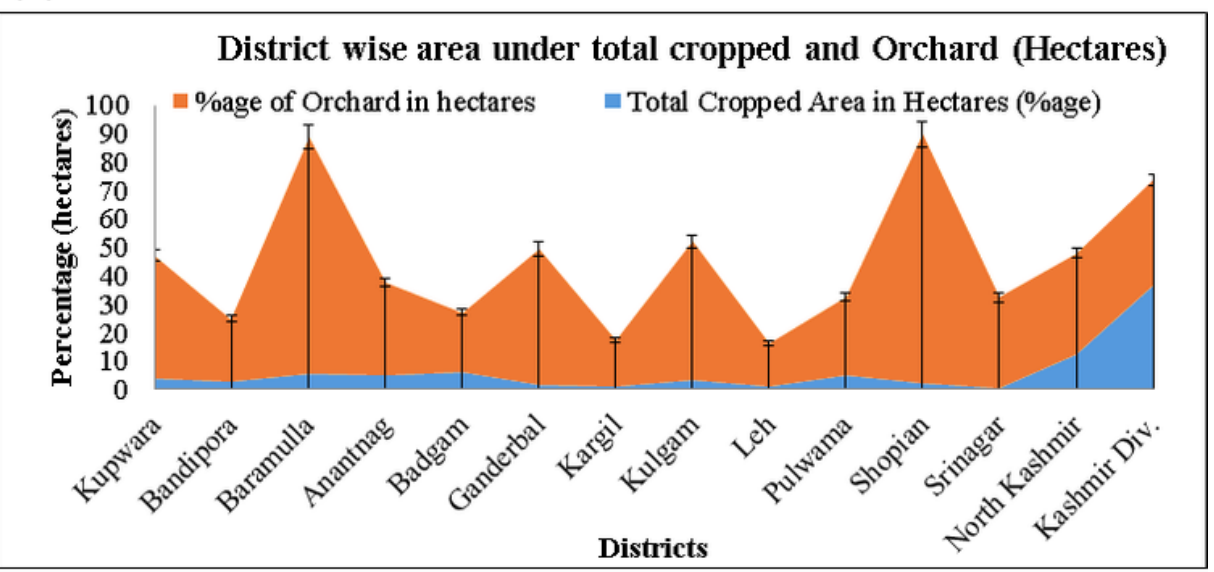

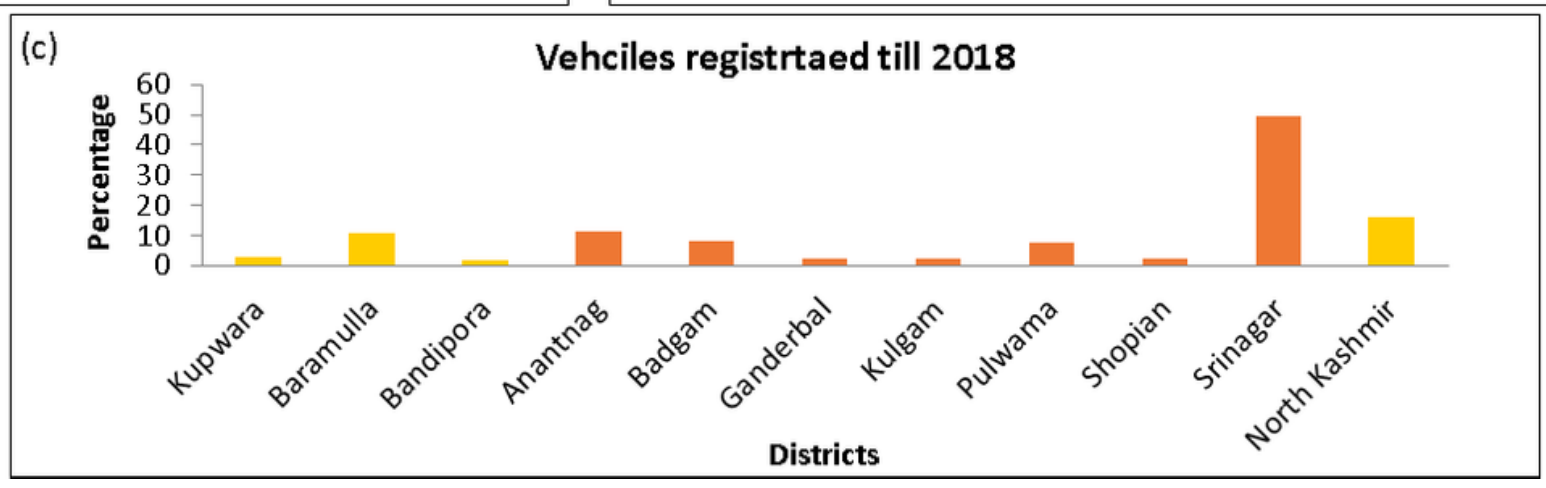

Figure 5

(a-c) Local source of air pollution (Fuel used for cooking, Horticulture residues and transport pressure). Source: Census of India 2011, JK Statistical Digest 2016, JK transport 2018. 

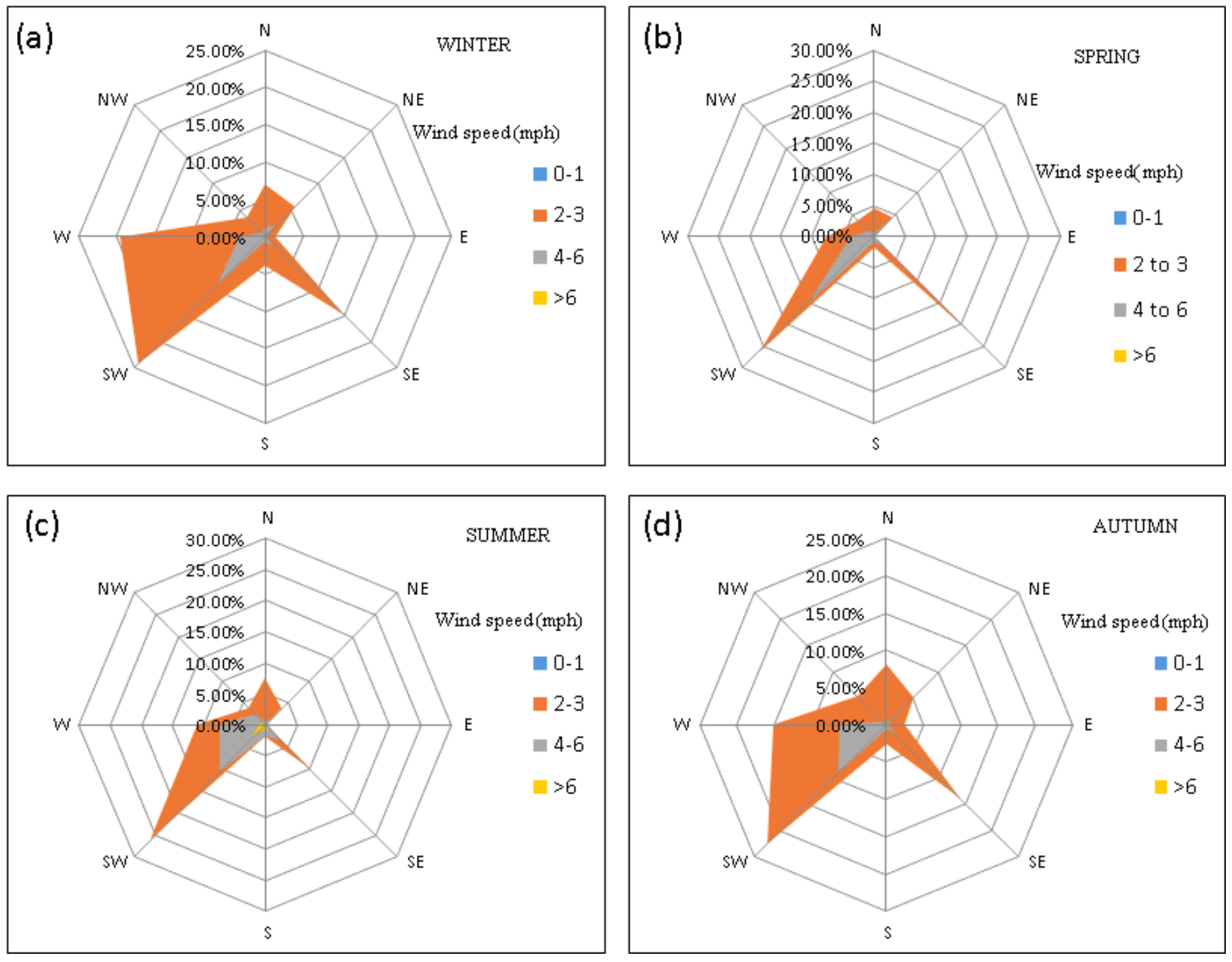

Figure 6

(a-d) Seasonal wind rose maps for 2013-2017. 

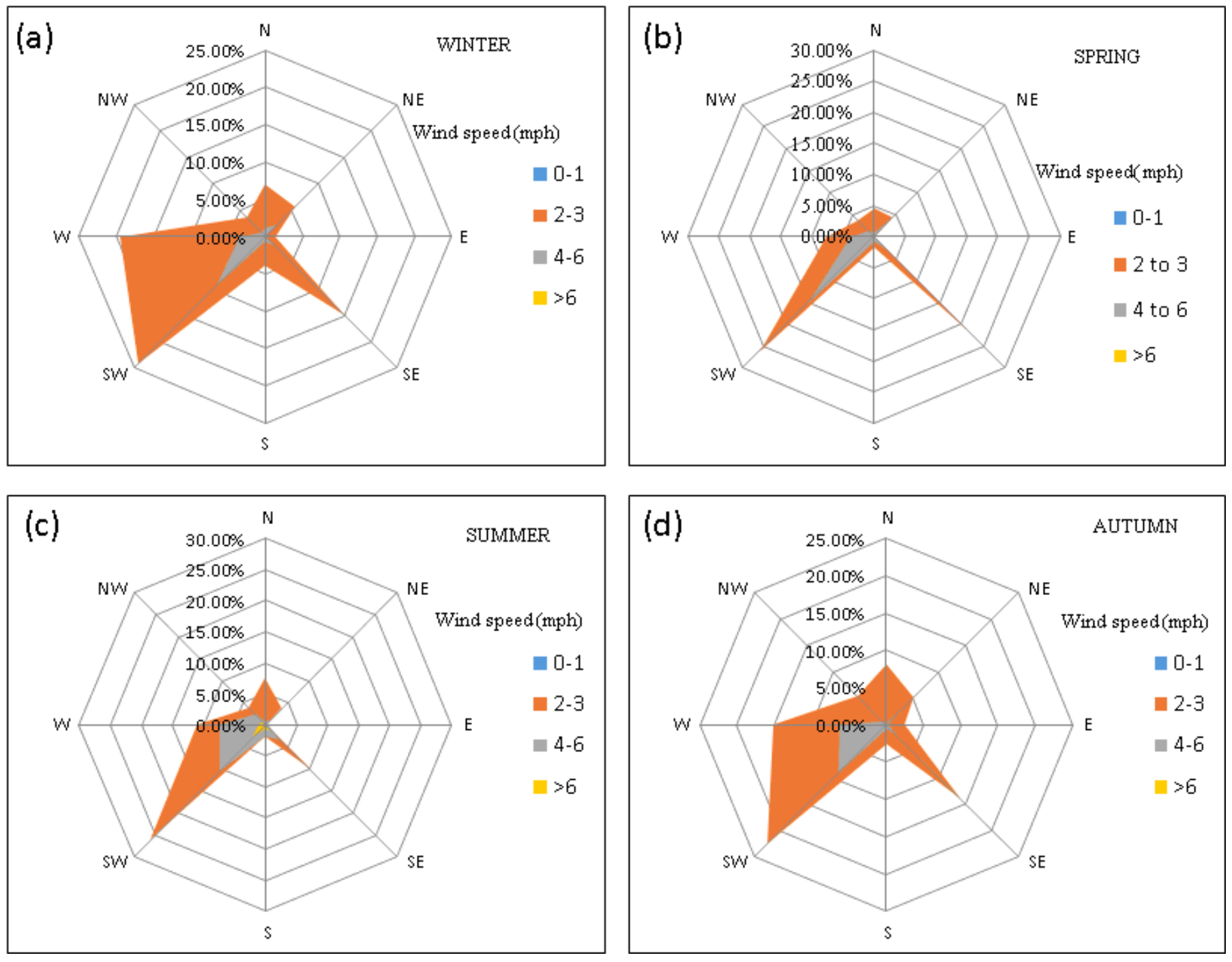

Figure 6

(a-d) Seasonal wind rose maps for 2013-2017. 
(a)

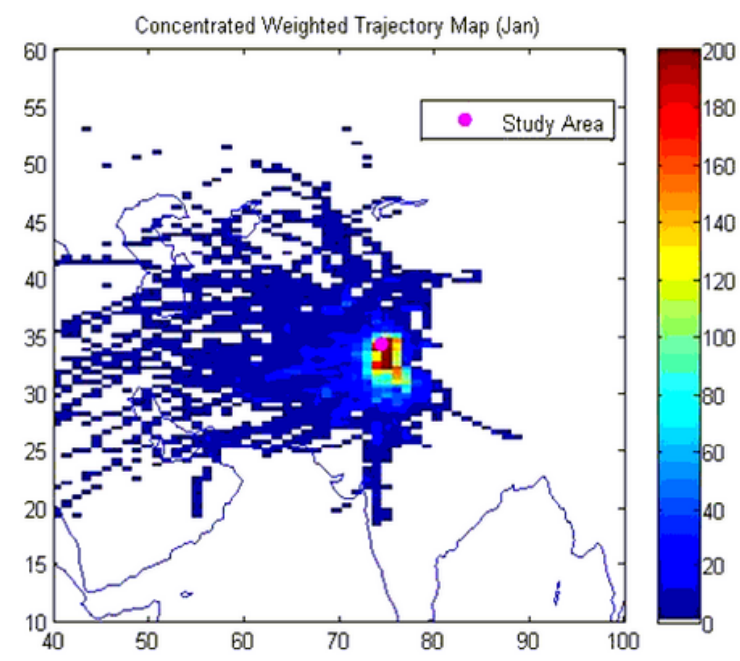

(c)

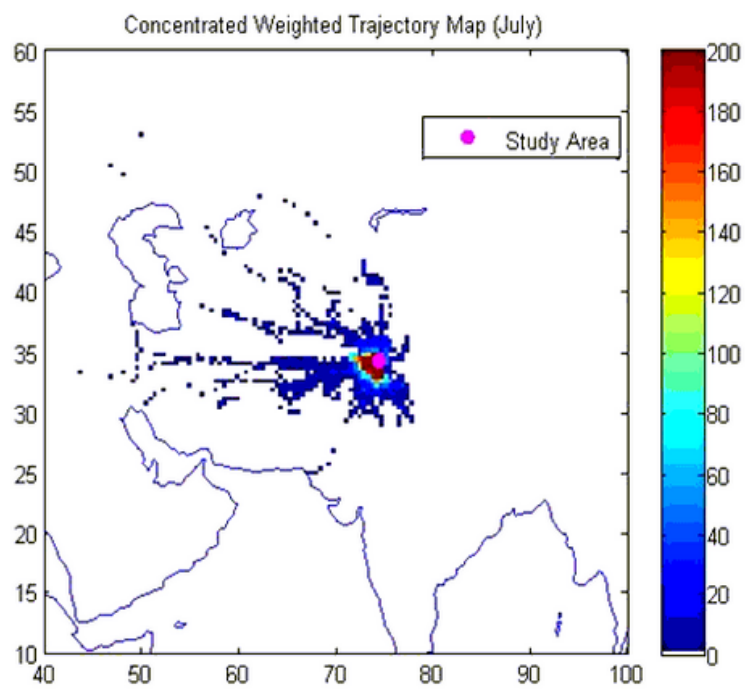

(b)

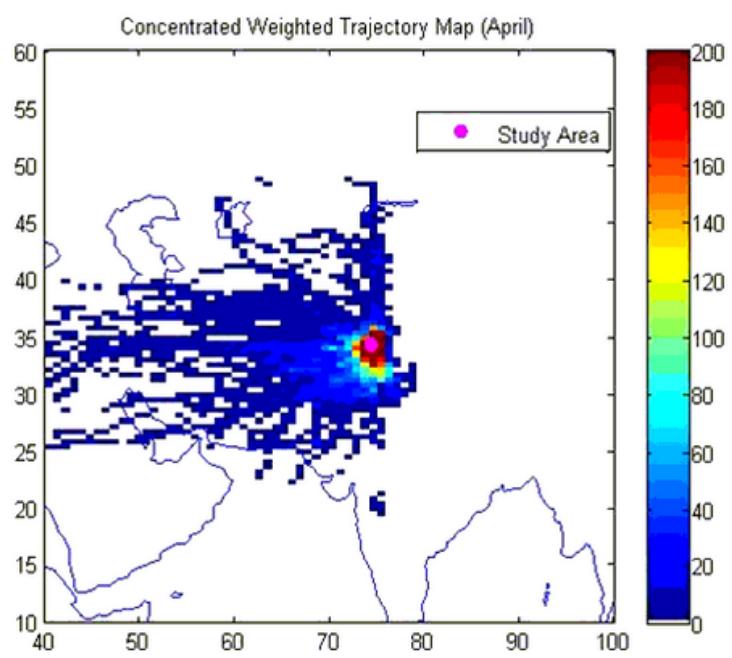

(d)

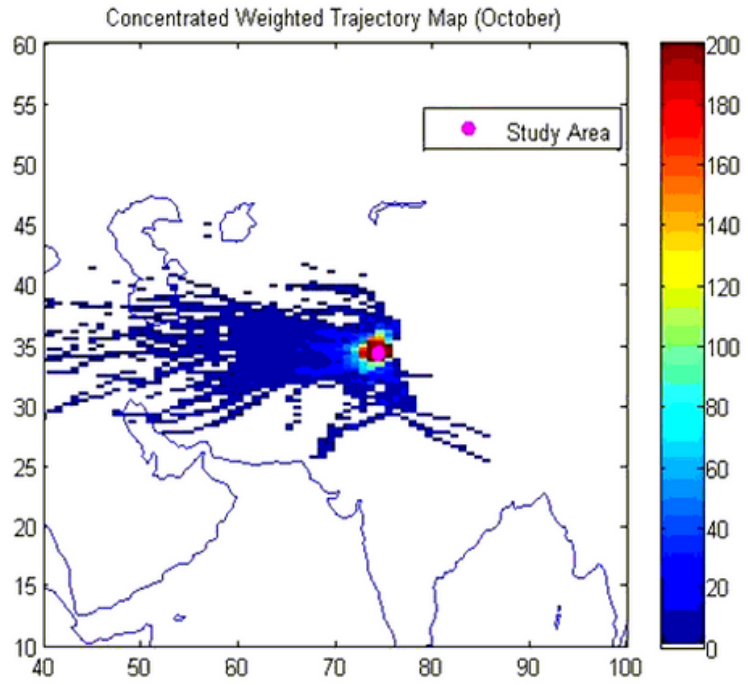

Figure 7

(a-d) The concentrated weighted wind trajectories for the months January, April, July and October for year 2013-2017. 
(a)

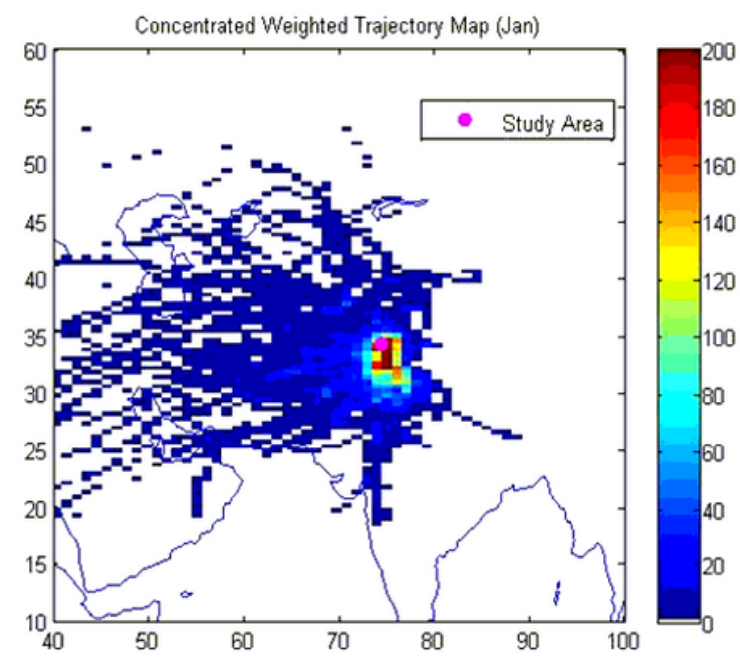

(c)

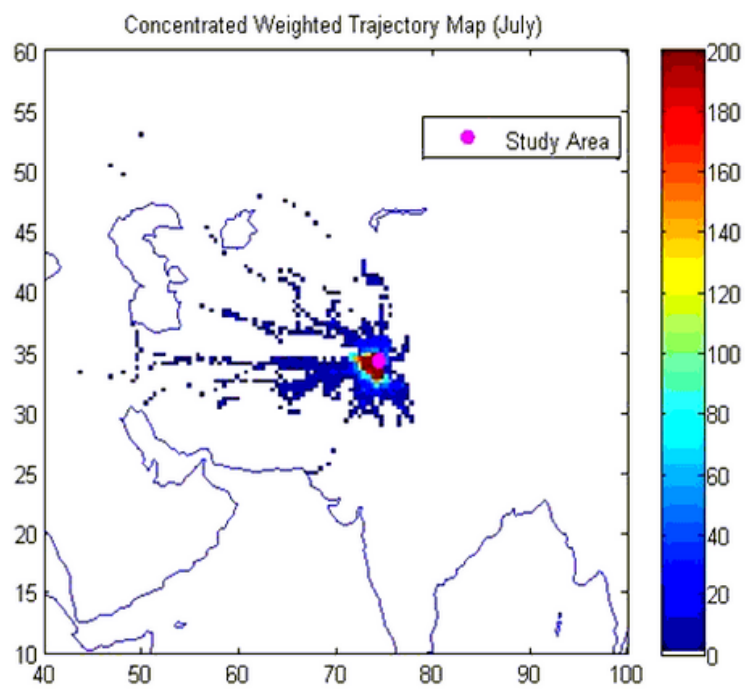

(b)

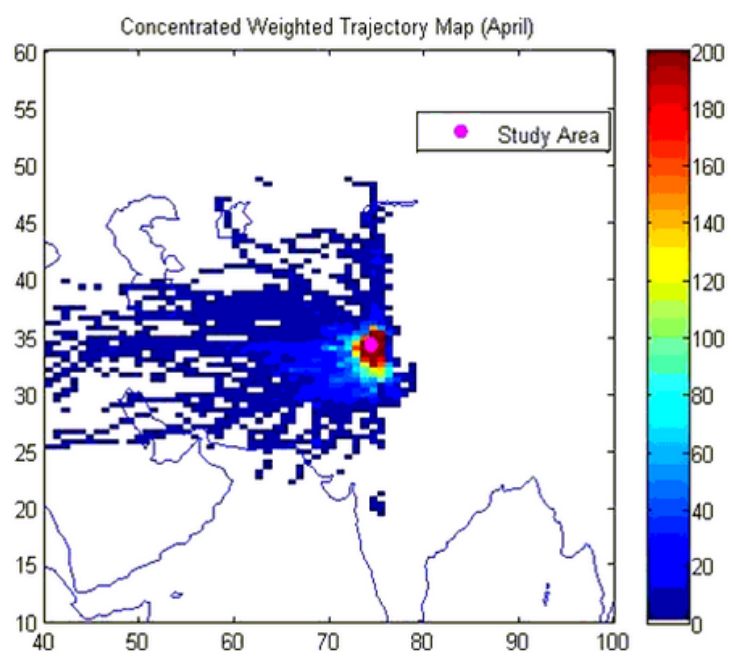

(d)

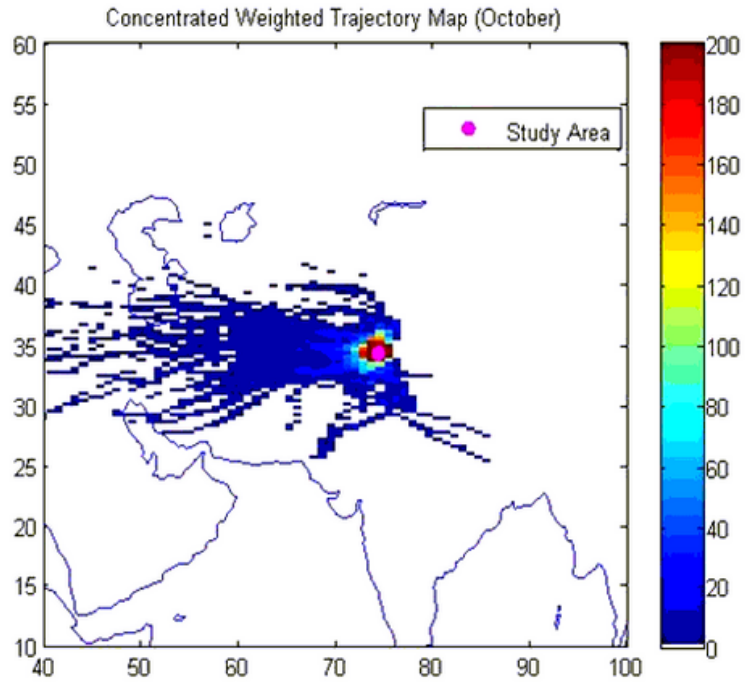

Figure 7

(a-d) The concentrated weighted wind trajectories for the months January, April, July and October for year 2013-2017. 